\title{
Impacts of Conflicts of Interest in the Financial Services Industry
}

Jeremy Burke, Angela A. Hung, Jack Clift, Steven Garber, and Joanne K. Yoong

RAND Labor \& Population

WR-1076

February 2015

This paper series made possible by the NIA funded RAND Center for the Study of Aging (P3OAG012815) and the NICHD funded RAND Population Research Center (R24HD050906).

RAND working papers are intended to share researchers' latest findings and to solicit informal peer review. They have been approved for circulation by RAND Labor and Population but have not been formally edited or peer reviewed. Unless otherwise indicated, working papers can be quoted and cited without permission of the author, provided the source is clearly referred to as a working paper. RAND's publications do not necessarily reflect the opinions of its research clients and sponsors. RAND® is a registered trademark. 
Impacts of Conflicts of Interest in the Financial Services Industry

Jeremy Burke, Angela A. Hung, Jack W. Clift, Steven Garber, and Joanne K. Yoong ${ }^{1}$

February 2015

\footnotetext{
${ }^{1}$ The work described in this report was supported by the Department of Labor, Contract DOL089327414. We thank Noreen Clancy and Eric Talley for comments, suggestions, and insights, and we thank Jeff Garnett and Katie Wilson for outstanding research assistance. Any errors are the sole responsibility of the authors.
} 


\begin{abstract}
Americans are increasingly being asked to take responsibility for their own retirement security. However, many people are ill-equipped to make financial decisions and have turned to professional financial advisors for help. While financial advisors often provide valuable services, it can be difficult for individual investors to evaluate the advice they receive and to identify when it has been influenced by a conflict of interest. In this literature review, we examine if and how financial advisors are influenced by their compensation schemes and how this influence impacts retail investors' financial well-being. We find empirical evidence suggesting that financial advisors act opportunistically to the detriment of their clients. However, the current body of literature generally cannot account for selection issues and the intangible benefits financial advisors provide.

In our broader review of conflicts of interest in the financial services industry, we find considerable evidence that investment analysts were excessively optimistic prior to regulation seeking to mitigate bias. There is mixed evidence on how this excessive optimism impacted investors, though the literature generally concludes that retail investors were more acutely impacted, as compared to institutional investors. We also find evidence that conflicts of interest extend to mutual fund management, with actively managed funds imposing sizeable trading costs and brokerage commissions which are not easily observed by retail investors.

Regulation and disclosure are often suggested methods for reducing bias. We find evidence that regulation designed to mitigate conflicts of interest can help reduce the prevalence of biased advice, but regulation that penalizes bad advice may be less effective because bias may be unconscious. Disclosure is unlikely to be an effective strategy if employed in isolation, but may be an important part of a comprehensive mitigation strategy.
\end{abstract}


Interactions between individual investors and financial advisors have changed considerably over the past few decades as financial service providers have expanded their range of services. Furthermore, as retirement assets have shifted from professionally managed accounts to individually directed accounts, Americans have had to take greater responsibility in planning for retirement. At the end of 2009, Americans held 8.3 trillion dollars in self-directed retirement plans, up from 4.8 trillion dollars at the end of 1998 (Investment Company Institute, 2010). Further, at the end of 2010 Individual Retirement Accounts (IRAs) held an estimated 4.7 trillion dollars, more than a quarter of total US retirement assets (Investment Company Institute, 2011a).

A large body of literature investigating individuals' financial literacy suggests many Americans are ill equipped to bear this responsibility. Lusardi and Mitchell (2007a, 2011), for example, argue that investing is a complex undertaking that requires consumers to gather, process, and project data on compound interest, risk diversification, and inflation, as well as to accumulate knowledge of the asset universe. Their findings suggest that most of the U.S. population is not sufficiently financially literate to cope with the burden of post-retirement. For example, in 2004 , only half of adults close to retirement age and older were able to correctly answer two simple questions regarding interest compounding and inflation, and only one-third correctly answered these two questions and a question about risk diversification (Lusardi and Mitchell, 2006, 2007b).

The increasing responsibility of individuals for their income security in retirement, the increasing complexity of retirement investment products available, and the absence of a corresponding increase in financial literacy among individuals, all point to the large/substantial impact that financial professionals can have on the lives of average Americans. A 2009 survey found that the number of investment options available in Defined Contribution pension plans ranged from as few as 3 to as many as 100, with an average around 15 (Deloitte, 2009). A different survey conducted in 2010 by PLANSPONSOR of Defined Contribution plan sponsors and clients indicated that the number of plan investment options increased by $10 \%$ from 2009 to 21.4 investment products on average (PLANSPONSOR, 2010). Individuals rely on financial advisors to help them plan for retirement and make decisions on investing their retirement savings; other professionals in the financial services industry also have impacts on the returns produced by those investments.

However, it can be difficult for individual investors to judge the performance of financial services professionals, or to understand when the incentives of financial professionals may be affected by conflicts of interest. In this review, we look at key areas in which conflicts of interest may be damaging to individual investors. We dedicate the most attention to the roles and 
incentives of financial advisors, but also include evidence on related areas that may provide useful insights and parallels, as laid out below:

1) Effects of advisors' compensation schemes

2) Bias in analyst reports

3) Agency problems in mutual fund management

4) Survey and experimental data

5) Regulation and Disclosure

6) Bias in audits

7) Psychology perspectives on conflicts of interest

We draw from academic literature, government reports, industry research and a range of other sources to address these issues, highlighting any available empirical work that can help quantify the effects of conflicted behavior on investor outcomes.

1) Effects of advisors' compensation schemes

Regulators have long been concerned with how compensation schemes influence financial advisors' recommendations to investors and their ultimate impact on investors' financial wellbeing. Many investors have low levels of financial literacy and could, in principle, benefit from expert financial advice. However, if an advisor's incentives are not aligned with those of his or her client, the advice may be of little value or potentially even damaging to the client's interests.

Howat and Reid (2007) present a useful taxonomy of the ways in which broker compensation in the mutual fund industry may lead to conflicts of interest. In directed brokerage, mutual funds agree to direct some amount of their trades through a particular broker (who earns commissions for executing those trades), in exchange for the broker promoting those funds to potential investors. This practice was banned by the U.S. Securities and Exchange Commission (SEC) in 2004. Relatedly, soft dollar commissions are an arrangement whereby mutual funds direct trades to brokers who in turn provide research and other services to the funds as part of their transaction commission; this has the effect of removing research costs from a fund's prospectus fee table (and expense ratio), 'hiding' them instead in the fund's transaction costs. This practice does not create the identical incentive for conflicted advice from a broker as directed brokerage. In directed brokerage arrangements, the broker receives incentives for promoting particular funds, and these funds may not be the optimal recommendation for the client's investment portfolio. In soft dollar commission arrangements, the broker is not given a 
direct incentive to bias the advice that he gives to the client. ${ }^{2}$ However, the authors argue this practice may raise a conflict of interest between mutual fund managers and their investors. The authors argue that this arrangement may not serve the interests of fund participants if fund managers choose brokers based on their ancillary services rather than seeking the broker who can best execute trades at the lowest cost to investors. 'Shelf-space' practices involve mutual funds making payments to broker-dealers who sell the funds' shares, sometimes under the guise of reimbursing the broker-dealer for expenses; by making the payments, the mutual fund buys 'shelf-space' on the broker-dealer's menu of products offered to investors, and the broker is potentially incentivized to recommend a product that may not best fit the circumstances of their clients. Differential Cash Compensation is the practice of a firm providing different levels of compensation to a broker depending on whether the fund sold is a proprietary fund (offered by the broker's employer), partnered fund (offered by a partner firm who pays cash in return), or a non-affiliated fund.

Howat and Reid also trace the evolution of these practices, and note that the shelf-space and differential cash compensation practices arise from ' $12 b-1$ ' plans which allow certain expenses to be paid out of fund assets, and which have led to different classes of shares within funds (e.g., high initial transaction payment with low annual fees, vs. low initial transaction payment with high annual fees) that may be appropriate for different types of investors. They argue that soft dollar commissions should be made illegal in the same way as directed brokerage, because the bundled commission makes transparency difficult or impossible. Nevertheless, they argue that the shelf-space / differential compensation practices should be exposed to enhanced disclosure rather than eliminated altogether, as it is possible to make explicit the potential conflicts of interest and allow investors to make up their own minds, and, they argue, the different classes of mutual fund shares "represents an advantage for potential shareholders, which we feel overcomes the associated costs, and the conflicts of interest for financial advisers".

Many of these issues, and analogous issues in other investment advice relationships, have been investigated and criticized by consumer advocates, regulators and watchdogs, in the US and elsewhere, for many years. ${ }^{3}$ In the UK, the Financial Services Authority (FSA) found significant evidence of misselling of personal pensions to consumers who were wrongfully advised to leave (or to not join) their employer-sponsored pension plans between 1988 and 1994; the FSA levied fines of 11.8 billion GBP on the advising firms (FSA, 2002). The use of soft-commission dollars to

\footnotetext{
${ }^{2}$ Although the authors cited do not discuss broker-client conflicts of interest in the context of soft dollar commissions, there may be an indirect conflict of interest whenever brokers and managers maintain a close relationship or brokers rely on managers for a significant part of their income

${ }^{3}$ See, e.g. "Avoiding Trouble with Stockbrokers" (1995), "Let the Buyers Be Aware" (1998), Grant (2002), "Going for Brokers" (2004), "Seller beware"(2004), "Cost of Conflicts" (2007), and Palaveev (2008).
} 
pay brokers for research and other services was a bone of contention in the early 2000s ("Hard to Stop," 2001, "How to Pay Brokers," 2001, "FSA seeks revamp," 2003), were analyzed by Oxford Economic Research Associates (OXERA) (2003), and regulated by the FSA in 2005 (FSA, 2005). More recently, the FSA has announced new rules which, from December $31^{\text {st }} 2012$ onwards, will ban the use of commission-based compensation for advisors of group personal pensions, despite concerns raised by some in the investment industry that the resulting change to fee structures may discourage employees from joining employer-based plans ${ }^{4}$ (FSA, 2010; Jones, 2010).

\section{Drawbacks of Fee-based compensation}

While many believe commission-based compensation for advisors leads to clear conflicts of interest, others argue that the issues are less clear-cut. Duska (1999) argues that agents and brokers are motivated not only by economic incentives, but also by ethics, and are capable of acting in ways that economic determinists would not predict. Robinson (2007) argues that alternative forms of compensation for financial advisors, such as asset-based fees or flat fees, also have potential conflicts of interest and principal-agent issues - flat fees present the fewest conflicts of interest, but also provide little accountability for future fund performance, compared with recurring asset-based percentage fees in which future compensation is directly tied to fund performance. ${ }^{5}$

A fees-only model may not benefit all investors: some have argued that moving to a fully feebased system may price less affluent investors out of the market for advice altogether, as reasonable fees would amount to a large up-front expense when compared to the assets of a small investor (Opiela, 2005). In addition, some firms were found guilty of fraud after moving some clients from commission-based accounts into fee-based accounts when it was clear this action would result in higher costs for the clients with no additional benefits (Pressman and Borrus, 2005).

There is evidence that some American consumers may prefer the commission model. Specifically, a 2011 Cerulli Associates survey of 7,800 households found that 47 percent would prefer to pay commissions rather than asset-based fees (preferred by 27 percent), lump-sum

\footnotetext{
${ }^{4}$ Some argue that elimination of commissions will require higher up-front fees being charged and passed on to employees; and that this (a) would discourage workers from joining if the initial payment eliminated most of the benefit they would normally receive through employer-matching, and (b) would be damaging to workers who frequently change jobs, as they would incur this 'start-up' cost each time they change plans.

${ }^{5}$ Among those using fees rather than commissions, flat fees and retainers may be easier to justify to long-standing clients who are convinced a financial planner has added value than to new clients, particularly as the flat fees need to be quite high if they are to maintain the same level of revenue for the advisory firm as traditional percentage fees calculated based on 'assets-under-management' (Opiela, 2006).
} 
retainer fees (18 percent) or hourly fees (8 percent). However, it is important to keep in mind that a large proportion of those investors (33 percent) did not know how they currently pay for investment advice, with another 31 percent believing that the advice they currently receive is free ("Commissions Win The Day Over Fees," 2011) 6 . These latter results are consistent with findings in Hung et al. (2008), in which they report household survey results on methods of payments for financial services, including advice. The data suggest that many respondents are confused about their methods of payment and/or their type of financial service provider. For example, of the respondents who indicate that they receive advisory services from an investment advisor, 19 percent reported that they pay for these advisory services based on a percentage fee, and 22 percent indicated that they pay commissions. However, the authors also find that 97 percent of SEC-registered investment advisors that are not registered brokerdealers reported that they are compensated by asset-based fees, and only 10 percent reported that they receive commissions. ${ }^{7}$

The impact of moving from commissions to fees for financial planning has led to a significant decrease in income for some planners: in a 2003 survey by Cerulli Associates, 50 percent of planners who had moved to a predominantly fee-based model reported a "serious" decline in income ("Marching Toward Fees," 2003). In our assessment, some possible causes for this decline in income are that fees generate less revenue than commissions for these planners, or that their customer bases shrunk due to the change in compensation scheme. The survey does not allow for discrimination between these potential causes. However, given the evidence cited in the previous paragraphs, it is possible that investors who prefer commissions or were priced out would leave their financial planner.

\section{Theoretical models of financial advice}

Several papers present theoretical models on financial advisors and the conflicts of interest that may arise in an advisory relationship. Stoughton, Wu and Zechner (2011) show that financial advisors can reduce information costs between portfolio managers and investors, and may serve as a price discrimination mechanism. They find that the existence of advisors benefits investors of all wealth and financial sophistication levels, unless there are "kickbacks," which are defined as rebates from portfolio managers to advisors. In their model, these rebates play a role in promoting market efficiency and increase surplus to the portfolio managers: they are

\footnotetext{
${ }^{6}$ See also "Professionals Prefer Impartial Fee-based Advice" (2003) for evidence that an informed subset of British investors prefer fees to commissions

${ }^{7}$ It is also a consistent finding in financial literacy research that investors are ignorant or mistaken about fees that they pay for financial services and products in general (not just advice). For further reading, see Dominitz, Hung, and Yoong (2009) or Bell et al. (2010).
} 
used as a price-discrimination mechanism, allowing portfolio managers to charge different prices to investors depending on wealth and therefore extract greater surplus than would be possible with a single price. However, the existence of rebates makes investors worse off. In their model, if all investors are sophisticated in that they fully are aware and understand the impact of rebates on their net returns and are not susceptible to marketing pressure, then only high net worth investors are negatively impacted by kickbacks. If all investors are unsophisticated, then investors of all wealth levels are negatively impacted by kickbacks. Their model does not allow for the simultaneous existence of sophisticated and unsophisticated investors as in the "real world." However, given the low levels of financial literacy in the United States, and the studies cited above about ignorance of fees for financial advice, we believe that the model in which investors are unsophisticated is the more realistic model.

A related argument for efficiency of kickbacks is given by Inderst and Ottaviani (2009a), whose model implies that if customers are naïve (do not anticipate the incentives of advisors) they get exploited by the kickback arrangement, but if customers are "wary" in that they anticipate the incentives of advisors, then the kickback system provides an incentive for intermediaries to put forward more effort in information-gathering; eliminating kickbacks would help naïve investors but harm wary investors. ${ }^{8,9}$ Our assessment here is similar to that stated above concerning Stoughton, Wu, and Zechner (2011). Specifically, the low levels of financial literacy in the United States and findings on investor ignorance of compensation structures for advisors indicate that the naïve investors in this model are more similar to the "typical" investor than are the wary investors.

Krausz and Paroush (2002) provide insights into how the characteristics of investors may influence how advisors behave: they show that conflicted advisors have less incentive to push risky assets if the investor has high tolerance for risk (as this means the investor already pursues a portfolio likely to maximize advisor revenue), and less incentive to give misleading advice if the investor is wealthy (as wealthy investors have greater power to punish the advisor by taking their large assets to another broker). Highly risk-averse investors with relatively small accounts are therefore particularly vulnerable to exploitation in their model. The authors note, as anecdotal evidence, that most lawsuits arising from a 1993 banking scandal in Israel were filed by retirees and old widows.

Inderst and Ottaviani (2009b) present a further perspective on the issue of misselling financial products: it is challenging for a firm to incentivize its employees to exert high levels of effort to

\footnotetext{
${ }^{8}$ Gorter (2012) extends Inderst and Ottaviani (2009a) by allowing both advisors and intermediaries to advise on product suitability and finds that banning commissions may yield little welfare benefits.

${ }^{9}$ Inderst and Ottaviani (2012) extends Inderst and Ottaviani (2009a) by allowing the option for advisors to charge fixed fees for advice and shows that when consumers may be naïve profits are maximized by not charging a fixed fee and instead levying higher commissions that may distort advice.
} 
sell products without simultaneously encouraging them to missell products. Firms may impose on their employees standards for reasonable selling, but costs of ensuring compliance are nonnegligible. One result from their model is that credibly transparent compensation schemes can produce higher suitability standards for a given level of willingness-to-pay from the customer while also benefiting the firms, but that in the absence of regulation customers may not find voluntarily disclosed compensation schemes to be credible.

Bolton, Freixas, and Shapiro (2007) present a model of competition between banks, and show that if there are reputation costs for bad advice in a competitive market, this should decrease the effects of conflicts of interest and lead to entirely truthful disclosure. This is particularly credible when a one-stop bank can provide a diverse enough range of products that they can recommend different products to suit different people, rather than facing a situation where a truthful recommendation would force an investor to go elsewhere for the appropriate product. However, it is important to note how the reputation costs are modeled. In particular, after selecting a product, an investor can immediately detect when he has been given bad advice, and a bank's reputation is known to all potential investors. In reality, it can be very difficult for investors to judge whether or not the advice they receive is good advice, especially for the large numbers of investors who struggle with financial literacy. Even if investors could make that judgment, it would most likely take several years to do so. The assumption that a bank's reputation could be known to all potential investors is likewise unrealistic, but there is evidence that reputation and "word-of-mouth" are important in the financial services sector. For example, Hung et al. (2008) find that over $75 \%$ of investors who use a financial service provider found their provider through referral, either professional or personal.

\section{Empirical evidence}

Recent audit studies suggest biased investment advice may be pervasive. Mullainathan, Noeth, and Schoar (2010) sent trained auditors posing as regular customers to financial advisors focused on the lower end of the retail segment (auditors were assigned portfolios between $\$ 45,000$ - $\$ 55,000$ or $\$ 95,000$ - $\$ 105,000) .{ }^{10}$ While the advisors generally attempted to match portfolios with personal characteristics consistent with traditional theory, they displayed a dramatic bias towards actively managed funds. In nearly 50 percent of visits an actively managed fund was suggested, while only $7.5 \%$ of advisors promoted an index fund. Notably, even when presented with an efficient portfolio by the auditors, the advisors frequently

\footnotetext{
${ }^{10}$ This segment of the market is of particular importance for IRA investors. Based on a sample of more than 10 million IRA investors collected from a range of mutual fund and insurance companies, the Investment Company Institute (hereafter referred to as the ICI Study) estimates that at the end of 2007 approximately $78 \%$ of traditional IRA investors had a balance less than $\$ 100,000$ (Investment Company Institute, 2011a).
} 
suggested a change to actively managed funds. Advisors in the sample were also generally supportive of portfolios chasing returns, which may result in increased advisor fees. ${ }^{11}$

A related study conducted by the Australian Securities \& Investment Commission (2006) found that advisors were 6 times more likely to offer "bad advice" (advice that was subjectively determined not to have considered key factual issues, did not fit the client's needs, or was likely to leave the client worse off) when the advisor had a conflict of interest over compensation (e.g., commissions) and three times more likely when suggesting an associated product (e.g., an in-house fund). The study also found that consumers were rarely able to detect bad advice. Investors in Australia, however, may be less protected from broker conflicts of interest than investors in the US. Cummings, Johan, and Li (2011) report the Australian Securities Exchange doesn't specifically prohibit brokerages from making trades that do not fit with their clients' interests nor are investors explicitly protected from improper execution issues. ${ }^{12}$ An earlier study in 2002 by Charles River Associates combined an audit study with an econometric analysis to examine whether commissions influenced financial advisor recommendations and harmed investors in the UK (Charles River Associates, 2002). The authors found scant evidence of bias in most of the financial services market, but did find evidence that increases in initial commissions on distribution bonds (tax advantaged investments comprised of equities and bonds) and withprofit bonds (lump sum investments in pooled investment funds normally run by insurance companies) were positively associated with increases in market share (empirical analysis). A 1 percent increase in the size of initial commission was associated with a $0.62(0.71)$ percentage point increase in market share in the distribution bonds (with-profit bonds) market. The audit study also found some evidence of bias in advice given on Individual Savings Accounts (ISA). ${ }^{13}$ Approximately 1 in 5 advisors failed to recommend an ISA (the product subjectively determined

\footnotetext{
${ }^{11}$ Berk and Green (2004) develop a theoretical model suggesting return chasing behavior is not necessarily irrational despite the fact that performance does not persist. In their model, superior past returns are evidence of manager skill. However, there are decreasing returns for managers in employing their ability and new money flows into funds to the point at which future expected excess returns are competitive.

${ }^{12}$ Cumming et al. (2011) create measures of investor protection for 42 countries/stock exchanges between January 2006 and October 2008, including an index for how well investors are protected from broker-agency conflicts of interest (trade through, improper execution, exchange members' use of the exchange name, sales and telemarketing restrictions, and rules on fair dealing with customers). When creating the broker-agency conflict index, the authors include information explicitly specified in the rules of each exchange, but do not include guidelines from professional associations.

${ }_{13}$ ISAs are similar to IRAs in that both receive favorable tax treatment, have annual contribution limits, are not directed by an employer, and provide access to a range of investments, including stocks and cash equivalents. Additionally, similar proportions and types of investors hold IRAs and ISAs. Halifax reports approximately $37 \%$ of households in the UK held an ISA in 2007/08, with approximately $40 \%$ of ISAs held by investors aged 55 or older (Halifax, 2010). An Investment Company Institute survey found that approximately $39 \%$ of US households held an IRA in 2011, with approximately $39 \%$ of IRAs held by investors aged 55 or older (Investment Company Institute, 2011d). However, in contrast to IRAs, income and capital gains received in an ISA are generally not taxed even at withdrawal. Also, investments in an ISA can be withdrawn at any time without restriction or penalty (other than a potential notice period) http://www.hmrc.gov.uk/leaflets/isa-factsheet.pdf
} 
to be the most appropriate), recommending bonds with initial commissions 3.7 percentage points higher on average. The authors calculate that these biases result in $£ 140$ million in detriment to investors annually. We note, however, that the figure relies on strong assumptions that the small sample of advice received in the audit study (72 consultations) is representative and that consumers would act in accordance with the advice received.

Biased advice may also be pervasive in sales seminars. Between 2006 and 2007, the SEC investigated 110 "free lunch" sales seminars targeted to seniors and retirees for compliance with securities laws and regulations (SEC, 2007). ${ }^{14}$ Most of the firms examined were brokerdealers, and many were also registered as investment advisers. In 63 (57\%) of the examinations, investigators concluded firms used advertising that featured misleading or exaggerated claims about investment safety and expected returns. In 25 (23\%) of the examinations, investigators found evidence that unsuitable investment option recommendations (subjectively defined based on the consumers investment objectives or time horizon) were made during the presentation or following the seminar when an attendee opened an account. Further, in 14 examinations investigators found indications of possible fraud involving serious misrepresentation of investment characteristics, liquidations of accounts without customer knowledge, or the sale of fictitious investment options. While the sample investigated revealed deficiencies in the advice offered, it is important to note examinations were not randomly assigned, but were selected based on a risk assessment designed to identify the highest risk of possible violations. Consequently, the study's results may not generalize beyond the population examined.

Investors may also receive conflicted advice about whether to rollover assets from an employer sponsored plan to an IRA. In a 2011 report, the Government Accountability Office (GAO) notes cross-selling IRA rollovers to plan participants is an important source of revenue for $401(\mathrm{k})$ plan service providers (GAO, 2011). However, rolling over assets from an employer sponsored retirement plan to an IRA may not be in the best interest of account holders. Since individuals' IRA account balances are usually not large enough to qualify for volume discounts, IRA owners typically pay higher fees than participants in 401(k) plans. The GAO spoke with one 401(k) plan record keeping firm who indicated that IRA owners generally pay fees in the range of 25-30 bp, but possibly as high as $65 \mathrm{bp}$, amounts that are two to three times higher than fees typically paid by $401(k)$ plan participants.

Dvorak (2014) compares the design of plans that 401(k) plan advisors help to create (client plans) to those that plan advisors use themselves (advisor plans) and finds that, in many

\footnotetext{
${ }^{14}$ These seminars may have disproportionate effects on IRA holders; at the end of 2007 approximately $42 \%$ of traditional IRA investors were age 60 or above and accounted for over $60 \%$ of total IRA assets. (Investment Company Institute 2011a).
} 
respects, advisors take their own advice. Clients and advisors tend to hold similar investments, fund families and fund categories. However, funds in clients' plans that are not in advisors plans have significantly higher expense ratios than funds clients and advisors share. ${ }^{15}$

The extent to which conflicted advice can harm advisees depends on how likely advisees are to follow advice. While empirical evidence on take-up of financial advice is limited, experimental work by Yaniv (2004) demonstrates that individuals in general tend to discount advice that is far from the individual's own opinion, a finding that suggests conflicted advisors straying far from the interests of their sophisticated clients risk being ignored; however, less knowledgeable individuals discount advice less, and may be more vulnerable. Relatedly, DeCarlo, Laczniak, and Leigh (2013) conduct an online experiment and find that consumers who are financially knowledgeable are more aware that high commission levels might impact an advisor's recommendations and are less likely to intend to purchase from an advisor with a high commission. However, the authors also find that more financially knowledgeable consumers are also more suspicious than their less knowledgeable counterparts of a commission-based salesperson's recommendation of a no-load fund and are less likely to intend to purchase, despite the fact that it is cheaper. Interestingly, experimental work by Gino (2008) finds that individuals tend to discount advice that they pay for to a lesser degree than advice they receive for free, seemingly because people are reluctant to treat the cost of advice as an ignorable sunk cost when making subsequent decisions. In a financial context, this might suggest that advice that has salient fees (such as specific financial planning fees) may be less likely to be discounted than advice paid for through bundled fees, or advice subsidized through kick-backs.

Recent work has suggested that biased advice does have material impacts on advisees' portfolios. ${ }^{16}$ Chalmers and Reuter (2014) examine data from the Oregon University System's DC plan to examine the impact of brokers on participants' investment choices. Between 1996 and 2007, participants joining the plan had the option of selecting a provider that offered a network of brokers that provided face-to-face recommendations or one of several participantdirected options. After 2007, however, new participants were only offered participant-directed options. The authors exploit this time-series variation in access to brokers and find that when the option to invest through a broker is no longer available, demand for the plan's default option increases differentially among participants with the highest predicted demand for brokers, especially when the default option is a target date fund (TDF). Using TDFs as a counterfactual, the authors find that actual broker clients earn significantly lower risk-adjusted returns and allocate more dollars to high-fee funds.

\footnotetext{
${ }^{15} 92 \%$ of the advisors in the sample received at least some indirect compensation.

${ }^{16}$ IRA holders may be particularly exposed to and impacted by biased advice. In a recent survey of 2,300 randomly selected IRA-owning households, approximately $78 \%$ of respondents that own traditional IRAs indicated they were held through professional financial advisors (Investment Company Institute, 2011b).
} 
Bergstresser, Chalmers, and Tufano (2009) use data from the Financial Resource Corporation (FRC) and Center for Research in Securities Prices (CRSP) to compare broker-sold mutual funds with direct-sold mutual funds over 1996-2004 and find that broker-sold funds provide investors inferior returns. More specifically, prior to including distribution fees, the authors estimate that on an annual asset-weighted basis broker-sold domestic equity funds (excluding index funds) underperform between 23-87 bp (depending on how funds are benchmarked or adjusted for risk). Similarly, in risk-adjusted asset-weighted specifications, directly sold bond funds (excluding index funds) outperform funds sold by brokers by 36-87 bp (depending on how funds are benchmarked or adjusted for risk). Broker-sold foreign equity funds are shown to underperform on an equal-weighted basis but outperform direct-sold funds on an assetweighted basis, though the latter effect is attributed to a few very large international funds distributed through one broker-channel fund family. The paper's results imply lower financial returns as a result of conflicts of interest, but the authors cannot rule out the possibility that brokers deliver substantial unobservable intangible benefits. A 2006 Investment Company Institute survey (subsequently discussed in more detail) finds that mutual fund investors do indeed receive numerous intangible benefits from financial advisors including help understanding various investment options, estate planning, peace of mind, help establishing savings goals, and time savings (Investment Company Institute 2007). However, several papers present evidence consistent with the hypothesis that conflicts of interest have a material impact on investors. For example, Bergstresser, Chalmers, and Tufano (2009), Christoffersen, Evans, and Musto (2013), Zhao (2005), and Hackethal, Inderst, and Meyer (2010) all suggest fund flows are positively associated with investment fees. Other studies, as discussed in more detail below, have similarly found that investors in the broker channel receive lower returns on their investments than investors in the direct channel (see "The Impact of Conflicts of Interest on Returns" table below). Additionally, investors may not be making fully informed tradeoffs when sacrificing returns for broker services. The "Commissions Win The Day Over Fees" (2011) study previously discussed suggests not all investors are aware of the full costs associated with financial advice.

The Impact of Conflicts of Interest on Returns

\begin{tabular}{|l|l|l|l|}
\hline Paper & Sample & Methodology & Annual Impact \\
\hline $\begin{array}{l}\text { Bergstresser, Chalmers, } \\
\text { and Tufano (2009) }\end{array}$ & $\begin{array}{l}\text { Domestic equity mutual } \\
\text { funds; 1996-2004 }\end{array}$ & $\begin{array}{l}\text { Compares annual } \\
\text { performance of broker } \\
\text { sold funds with direct sold } \\
\text { funds (prior to including } \\
\text { distribution fees) }\end{array}$ & $\begin{array}{l}\text { Broker sold funds } \\
\text { underperform by 23 -87bp } \\
\text { (depending on risk } \\
\text { adjustments) }\end{array}$ \\
\hline
\end{tabular}




\begin{tabular}{|c|c|c|c|}
\hline $\begin{array}{l}\text { Bullard, Friesen, and Sapp } \\
\text { (2008) }\end{array}$ & $\begin{array}{l}\text { Domestic equity mutual } \\
\text { funds, } 1991-2004\end{array}$ & $\begin{array}{l}\text { Investigates how load and } \\
\text { no-load fund investor } \\
\text { returns compare to a buy- } \\
\text { and-hold strategy }\end{array}$ & $\begin{array}{l}\text { Load funds underperform } \\
\text { a buy-and-hold strategy } \\
\text { by } 1.82 \text { percentage points, } \\
\text { more than double } \\
\text { underperformance for no- } \\
\text { load investors }\end{array}$ \\
\hline $\begin{array}{l}\text { Christoffersen, Evans, and } \\
\text { Musto (2013) }\end{array}$ & $\begin{array}{l}\text { Mutual funds with front } \\
\text { loads; } 1993-2009\end{array}$ & $\begin{array}{l}\text { Investigates whether load } \\
\text { sharing and revenue } \\
\text { sharing impacts returns }\end{array}$ & $\begin{array}{l}1 \text { percentage point } \\
\text { increase in load sharing } \\
\text { reduces excess return } 0.34 \\
\text { percentage points }\end{array}$ \\
\hline $\begin{array}{l}\text { Del Guercio, Reuter, and } \\
\text { Tkac (2010) }\end{array}$ & $\begin{array}{l}\text { Domestic equity mutual } \\
\text { funds, } 1996-2002\end{array}$ & $\begin{array}{l}\text { Compares returns for } \\
\text { actively (and passively) } \\
\text { managed funds in the } \\
\text { direct channel with } \\
\text { comparable funds in the } \\
\text { broker, institutional and } \\
\text { 'other' categories }\end{array}$ & $\begin{array}{l}\text { Direct sold actively } \\
\text { managed funds } \\
\text { outperform by } \\
\text { approximately } 1 \\
\text { percentage point }\end{array}$ \\
\hline $\begin{array}{l}\text { Del Guercio and Reuter } \\
\text { (2014) }\end{array}$ & $\begin{array}{l}\text { Domestic equity mutual } \\
\text { funds, } 1992-2004\end{array}$ & $\begin{array}{l}\text { Compares returns for } \\
\text { index funds with actively } \\
\text { managed funds in the } \\
\text { direct channel and } \\
\text { comparable funds in the } \\
\text { broker channel }\end{array}$ & $\begin{array}{l}\text { Direct sold actively } \\
\text { managed funds do not } \\
\text { underperform index } \\
\text { funds, but broker sold } \\
\text { actively managed funds do } \\
\text { underperform index funds } \\
\text { by approximately } 1 \\
\text { percentage point }\end{array}$ \\
\hline Friesen and Sapp (2007) & $\begin{array}{l}\text { Domestic equity mutual } \\
\text { funds, } 1991-2004\end{array}$ & $\begin{array}{l}\text { Investigates how load and } \\
\text { no-load fund investor } \\
\text { returns compare to a buy- } \\
\text { and-hold strategy }\end{array}$ & $\begin{array}{l}\text { Load funds underperform } \\
\text { a buy-and-hold strategy } \\
\text { by } 1.96 \text { percentage points, } \\
\text { approximately double the } \\
\text { underperformance for no- } \\
\text { load investors }\end{array}$ \\
\hline $\begin{array}{l}\text { Hackethal, Haliassos, and } \\
\text { Jappelli (2012) }\end{array}$ & $\begin{array}{l}\text { Customers of a large } \\
\text { German brokerage firm } \\
\text { and customers of a large } \\
\text { German commercial bank } \\
\text { over Jan 2003- Oct } 2005\end{array}$ & $\begin{array}{l}\text { Compares net returns of } \\
\text { advised and self-managed } \\
\text { accounts }\end{array}$ & $\begin{array}{l}\text { Log annual returns for } \\
\text { advised accounts are } \\
\text { lower by approximately 4- } \\
5 \text { percentage points }\end{array}$ \\
\hline Morey (2003) & $\begin{array}{l}\text { Mutual funds available to } \\
\text { US investors as of } \\
\text { December } 1992 \text { with at } \\
\text { least three years of return } \\
\text { history }\end{array}$ & $\begin{array}{l}\text { Compares out of sample } \\
\text { performance (1993-1997) } \\
\text { of load and no-load funds }\end{array}$ & $\begin{array}{l}\text { Load-adjusted returns for } \\
\text { no load funds are higher } \\
\text { by approximately } 1.3 \\
\text { percentage points }{ }^{17}\end{array}$ \\
\hline
\end{tabular}

Christoffersen, Evans, and Musto (2013) examine whether mutual fund flows and investor returns are consistent with brokers' incentives using data from the SEC and Morningstar on U.S. mutual funds from 1993 to 2009. The authors find that both load sharing (payments from sales

\footnotetext{
${ }^{17}$ Annualized from average mean monthly returns of $0.94 \%$ for no-load funds and $0.84 \%$ for load funds.
} 
loads consumers pay) and revenue sharing (payments from advisors' revenue) have a significant positive impact on funds' inflows, particularly when brokers are not affiliated with the fund sponsor. Additionally, load sharing is shown to be associated with lower performance; $1 \%$ more to the broker implies a 0.34 percentage point reduction in performance (fund's return minus the contemporaneous return of its category) over the next year. However, revenue sharing, which typically involves both upfront payments and continuing payments proportional to investment value, is not found to predict inferior returns in their analysis. Taken together, the findings imply that fee sharing alters broker incentives and can be particularly harmful to investors when brokers' incentives are not aligned with their clients' interests.

Other works have also found that loads impact inflows and are associated with inferior performance. Zhao (2005) finds that while no-load mutual funds receive larger flows than load funds, funds with higher loads receive greater flows than funds with smaller loads. ${ }^{18}$ This is consistent with there being separate markets (with "sophisticated" investors purchasing no-load funds and "unsophisticated" investors purchasing load funds, usually through a broker) and suggests that conflicts of interest induce advisors to direct customers towards mutual funds with higher loads. Relatedly, Hortacsu and Syverson (2004) estimate that investors who purchase load funds have higher search costs than those who purchase no-load funds. This may be the result of opportunism on the part of financial advisors, but it is also consistent with novice investors valuing the advisory services bundled with the purchase of load funds. Morey (2003) examines funds available to investors as of the end of 1992 with three years of return history and compares the out-of-sample performance of no-load and load mutual funds over 1993 - 1997. The author finds a significant difference in load-adjusted returns. The average mean monthly return for no-load funds was $0.94 \%$, while the average mean load-adjusted return for load funds was $0.84 \%$, a difference significant at the $1 \%$ level.

The Impact of Loads on Flows

\begin{tabular}{|l|l|l|l|}
\hline Paper & Sample & Methodology & Impact \\
\hline $\begin{array}{l}\text { Christoffersen, Evans, and } \\
\text { Musto(2013) }\end{array}$ & $\begin{array}{l}\text { Mutual funds with front } \\
\text { loads; 1993-2009 } \\
\text { (load sharing) } \\
\text { Mutual funds with }\end{array}$ & $\begin{array}{l}\text { Examines impacts of load } \\
\text { sharing and revenue } \\
\text { sharing on inflows }\end{array}$ & $\begin{array}{l}\text { 50bp more in load sharing } \\
\text { increases monthly inflows } \\
\text { by 0.0186 percent }\end{array}$ \\
\hline
\end{tabular}

\footnotetext{
${ }^{18}$ It should be noted that, due to data limitations, the author is unable to account for break points on front end load funds (or rebates which may be given to consumers) and uses the maximum load for these funds rather than average actual load.
} 


\begin{tabular}{|l|l|l|l|}
\hline & $\begin{array}{l}\text { defensive 12b-1 plans } \\
\text { (revenue sharing) }\end{array}$ & $\begin{array}{l}\text { sharing increases monthly } \\
\text { inflows by 0.588 percent }\end{array}$ \\
\hline Zhao (2005) & $\begin{array}{l}\text { Mutual funds with loads, } \\
1992-2001\end{array}$ & $\begin{array}{l}\text { Investigates whether load } \\
\text { funds with higher loads } \\
\text { receive higher flows }\end{array}$ & $\begin{array}{l}\text { A 1bp increase in } \\
\text { (maximum) front-end } \\
\text { loads increases quarterly } \\
\text { percentage inflows by } \\
\text { approximately 1.2bp }\end{array}$ \\
\hline $\begin{array}{l}\text { Hackethal, Inderst, and } \\
\text { Meyer (2010) }\end{array}$ & $\begin{array}{l}\text { Customers of a large } \\
\text { German bank; Aug 2005- } \\
\text { July 2007 }\end{array}$ & $\begin{array}{l}\text { Examines whether } \\
\text { investors who rely heavily } \\
\text { on advice generate more } \\
\text { bank revenue }\end{array}$ & $\begin{array}{l}\text { Customers who rely } \\
\text { heavily on advice generate } \\
\text { 20 percent more revenue } \\
\text { for the bank (consisting } \\
\text { mainly of loads) }\end{array}$ \\
\hline
\end{tabular}

The literature also suggests equity mutual fund investors, particularly those invested in load funds, display poor market timing. ${ }^{19,20}$ Bullard, Friesen, and Sapp (2008) examine domestic equity mutual funds from 1991 - 2004 and find that investors in load funds underperform a buy-and-hold strategy by 1.82 percentage points annually, more than double the performance gap experienced by no-load fund investors. ${ }^{21}$ Additionally, Class B fund shares (which often provide higher compensation to a broker than other shares) are found to perform the worst, underperforming a buy-and-hold strategy by 2.28 percentage points annually. In contrast, investors in no-load index funds don't experience any performance gap. While the evidence is consistent with brokers taking advantage of unsophisticated clients in order to increase commissions, the authors cannot rule out the possibility that clients are putting pressure on their brokers to chase returns. A 2004 Investment Company Institute survey of mutual fund shareholders, however, suggests that investors in the broker and direct channels display similar sensitivities to past performance, particularly short-run performance (Investment Company Institute, 2004). For example, $82 \%$ of survey respondents in the broker channel and $83 \%$ of respondents in the direct channel strongly or somewhat agreed with the statement "I am not concerned about short-term fluctuations in my mutual fund investments." In addition, investors in the two channels reported remarkably similar time frames for considering investment risks of equity or bond mutual funds $-4 \%$ of investors in the broker channel considered a time frame of less than a year compared to $5 \%$ of investors in the direct channel, while $29 \%$ in both channels considered a time frame of one to five years. As noted in Bergstresser, Chalmers, and Tufano (2009), this suggests investors in both channels are similarly predisposed to chasing returns and behavioral differences between the two groups may reflect advice received. Additionally,

\footnotetext{
${ }^{19}$ At the end of 2007, equity mutual funds accounted for approximately $32 \%$ of all IRA assets (Investment Company Institute, 2011a).

${ }^{20}$ Dichev and Yu (2011) find hedge fund investors also display poor market timing.

${ }^{21}$ In a closely related work, Friesen and Sapp (2007) employ a similar methodology and sample and find similar results. Load funds are found to underperform a buy-and-hold strategy by approximately $1.96 \%$ percentage points annually, about double the performance gap experienced by those invested in no-load funds.
} 
Mullainathan, Noeth, Schoar (2010) find advisors are generally supportive of return-chasing portfolios. Further, Hackethal, Haliassos, and Jappelli (2012) examine a survey of customers of a large German bank and finds that advisors significantly affect the timing of investors' trades; only $12 \%$ of respondents claimed they initiate contact and trading activity. Given the evidence just described, we believe it is unlikely that client pressure to chase returns is driving the inferior market timing displayed in the broker channel.

Several studies corroborate the market segmentation evidence suggested by the different characteristics and return performance of load and no-load fund investors. Del Guercio, Reuter, and Tkac (2010) find evidence that market segmentation in the mutual fund industry is driven by heterogeneous investor preferences. The framework rests on two key assumptions. First, the authors explicitly assume that while all investors value high after-fee returns, some investors also inherently value broker services (which may entail lower after-fee returns). Second, they assume that brokers have no incentive to recommend mutual funds that investors can purchase at lower cost on their own or through another intermediary - as a result, mutual fund families cannot serve both "do-it-yourself" and broker inclined customers because advice is unlikely to direct investors to low fee funds. Consistent with this view, only $3.3 \%$ of mutual fund families distribute funds through both the direct and broker channels. The authors also find that investments in portfolio management are higher in the direct channel, while mutual funds in the broker channel charge higher fees in order to compensate brokers for providing ancillary services to investors. As a result of the increased focus on performance, investors in actively managed funds in the direct channel earn higher returns (on the order of 1 percentage point per year) than investors in comparable actively managed funds in the broker, institutional and unclassified channels. Using similar methodology and data, Del Guercio and Reuter (2014) find that actively managed funds in the broker channel, but not the direct channel, underperform index funds.

Gil-Bazo and Ruiz-Verdú (2008) develop a theoretical model of the mutual fund industry in which fund quality is ex ante unobservable and a fraction of (unsophisticated) investors do not optimally use all available information. In this framework, there exists an equilibrium in which high-quality funds compete for sophisticated investors by charging lower fees, while low-quality funds seek to extract rents from unsophisticated investors through high fees. Gil-Bazo and RuizVerdú (2009) find evidence consistent with this strategic fee setting argument; mutual funds with worse before-fee performance charge higher fees. The authors posit that funds expected to perform poorly (or that have performed poorly in the past) raise fees and target less performance sensitive (less sophisticated) investors, often through increased marketing efforts (which increase distribution costs). 
Other recent works have focused more explicitly on the impact of advice. Hackethal, Inderst, and Meyer (2010) examine data from a large German bank and an associated customer survey to examine how advice impacts trading. The authors find that investors who rely heavily on advice generate more than $20 \%$ more trading volume ${ }^{22}$ and are significantly more likely to hold assets which their advisors have been incentivized to sell. As a result, customers who rely on advice generate $20 \%$ higher revenue from securities transactions for the bank. ${ }^{23}$ The survey results indicate that respondents are more likely to rely on advice when they are more confident in their advisor's expertise (or less confident in their own) and perceive less of a conflict of interest. Almost all customers in their sample believed they were being treated fairly. The study also indicates that advisors can have an impact on the frequency with which their customers trade; only $12 \%$ of respondents claimed they typically take the initiative before transactions, while $45 \%$ indicated their advisor usually or almost always initiates the trade. While the results are consistent with conflicts of interest negatively impacting performance, the authors are unable to analyze how reliance on advice impacts fee- and risk-adjusted performance.

Hackethal, Haliassos, and Jappelli (2012) also use data from a large German bank, as well as a German brokerage firm, to investigate how advised accounts perform compared to selfmanaged accounts. Defining advised accounts as those continually assisted over 2003-2006, the authors find that investors who relied on an independent (an advisor who is not an employee of a commercial bank) financial advisor (IFA) had lower net returns (monthly log returns, risk adjusted returns, and abnormal returns were all roughly 0.4 percentage points lower). Similarly, relying on a bank's financial advisor (BFA) reduced monthly log returns by 0.3 percentage points. ${ }^{24}$ Further, both IFA and BFA use was found to decrease ex post portfolio efficiency and increase account turnover, consistent with a conflict of interest created by commissions. IFAs and BFAs also appear to have pushed clients towards mutual funds, consistent with their compensation incentives. The paper also suggests that financial advisors are not simply taking advantage of unsophisticated consumers as they are more likely to be matched with richer, older and more experienced investors. While much of the evidence is consistent with harmful conflicts of interest, the authors cannot rule out the possibility that these investors are too busy

\footnotetext{
${ }^{22}$ The authors are unable to prove causality, but provide indirect evidence suggesting causality runs from reliance on advice to trade volume.

${ }^{23}$ A similar proportion of German and American investors seek professional financial advice. Hackethal, Inderst, and Meyer (2010) cite a 2004 survey of German investors finding more than $80 \%$ consult a financial advisor. A 2011 Investment Company Institute survey found 80\% of mutual fund holders who purchased outside of an employer-sponsored plan used a professional financial advisor (Investment Company Institute, 2011c).

${ }^{24}$ Cumming, Johan, and Li (2011) report that investors in the German stock exchange are less well protected against broker conflicts of interest than investors in US stock exchanges (NYSE and NASDAQ). In particular, since October 2007, the authors report that the German stock exchange doesn't have any explicit rules barring brokerages from making trades that aren't in their clients' interests.
} 
to manage their money themselves and are willing to pay a premium to have it managed for them. Results from a 2006 Investment Company Institute survey (discussed in more detail below) support the hypothesis that time-saving is an intangible benefit that investors receive from financial advisors: $44 \%$ of respondents with an ongoing relationship with a financial advisor indicated that a major reason they consult advisors is that they don't have time to make their own investment decisions (Investment Company Institute, 2007). However, as discussed previously, investors may not be aware of the size of the premium they are paying (“Commissions Win the Day over Fees," 2011; Hung et al., 2008).

While the empirical articles discussed to this point are consistent with brokers delivering conflicted advice that harms consumers, none of the articles concludes that clients would have been better off by foregoing advice. Even if people receive lower returns through a broker, consulting with a financial advisor may provide intangible benefits that customers value. A 2006 Investment Company Institute survey examined the benefits mutual fund holders claim to receive from professional investment advice (Investment Company Institute, 2007). Using a sample of 1,003 randomly selected households with median incomes of $\$ 75,000$ or more, the survey found respondents claimed to receive numerous services from their advisor including financial planning assistance, retirement asset management, access to tax planners and other specialists, and investment recommendations. Investors enjoy receiving access to financial expertise, help in ensuring they are saving enough, help improving their chances of growing assets, and peace of mind about their investments. Other cited benefits include explanations of investment options (73\%), making sure their estate is in order in case of tragedy (65\%), and not having time to make their own investment decisions (44\%). Nearly $75 \%$ of people who delegate or make investment decisions together with their advisor indicate they do so because of their advisor's financial expertise. However, some respondents appear to be aware of potential conflicts of interest; 1 in 4 claim they always conduct independent research to confirm recommendations and more than 4 in 10 say they sometimes do this research. Additionally, many respondents who no longer rely on financial advice and invest on their own do so in part because of a bad experience with a financial advisor previously ( $50 \%$ of respondents who used to work with a financial advisor). Moreover, $34 \%$ of respondents without a financial advisor cited "advisors put their own interests before those of their clients" as a major reason for not seeking professional advice, and $21 \%$ claim they are unsure how to find a trustworthy advisor. Consistent with Hackethal, Haliassos, and Jappelli (2012), the survey found older shareholders, shareholders with greater financial assets, and women were more likely to have an on-going relationship with a financial advisor. 


\section{Summary}

Our review of the literature finds there is substantial empirical evidence that financial advisors are influenced by their compensation schemes and that investors who purchase through advisors earn lower returns than those who invest autonomously. Mullainathan, Noeth, and Schoar (2010) and a study by the Australian Securities \& Investment Commission (2006) find that financial advisors display a bias towards actively managed funds and funds with higher fees. Christoffersen, Evans, and Musto (2013) and Hackethal, Inderst, and Meyer (2010) find that fund flows and investor holdings are sensitive to differences in advisor compensation, particularly sales loads. Gil-Bazo and Ruiz-Verdu (2008 and 2009) suggest funds expected to perform poorly may strategically target unsophisticated or performance insensitive customers. Bergstresser, Chalmers, and Tufano (2009), Christoffersen, Evans, and Musto (2013), Bullard, Friesen, and Sapp (2008), Friesen and Sapp (2007), Del Guercio, Reuter, and Tkac (2010), Del Guercio and Reuter (2014), Hackethal, Haliassos, and Japelli (2012), and Morey (2003) all present evidence that investors in the broker channel earn lower returns than investors in the direct channel.

However, it is important to bear in mind that these studies may have data limitations and in general cannot account for selection issues and the intangible benefits that investors may receive from financial advisors. A 2007 study by the Investment Company Institute finds that mutual fund investors do indeed receive numerous intangible benefits including help understanding various investment options, estate planning, peace of mind, help establishing savings goals, and time savings (Investment Company Institute, 2007). While investors who use financial advisors often value the auxiliary services they receive, many investors appear to be confused about or unaware of the total costs associated with advice and may feel differently if all costs were known (Hung et al. 2008). 


\section{2) Bias in analyst reports}

Conflicted advisors may give their clients individualized advice that leads them to make decisions that are not in their clients' best interests. Although stock analysts do not give personalized advice to individual clients, they do face conflicts of interest insofar as their personal incentives are not fully aligned with their assumed goal of giving unbiased and accurate recommendations to the public. ${ }^{25}$ While researchers have only recently begun to examine how personalized conflicted advice affects individual investors, there is a substantial amount of work examining bias in analyst reports.

Demski (2003) discusses a number of corporate conflicts of interest, including the relationship between analysts and investment banks. In general, analysts tend to issue optimistic earnings forecasts, and skew their recommendations towards "strong buy" and "buy" ratings, both of which behaviors are consistent with analysts attempting to curry favor with firms in order to secure investment banking business; analysts are more likely to 'follow' a firm if it has an investment banking relationship with their firm, and indeed firms may switch underwriters in order to be followed by a star analyst.

The Enron and Global Crossing scandals provide examples of alleged conflicted analysis that had significant consequences for investors. Legal proceedings following the collapse of Enron and Global Crossing alleged that analysts in the research departments of Merrill Lynch and Salomon Smith Barney were pressured to release misleadingly positive research reports in order to gain or retain investment banking business for their parent company (GAO, 2003a). Jack Grubman of Salomon Smith Barney and Henry Blodget of Merrill Lynch were fined \$19 million and were barred from working on Wall Street as part of a larger \$1.4 billion settlement between 10 investment firms and federal and state regulators (Hill, 2003).

On the other side, some authors argue in favor of conflicted analysis. Spindler (2005) argues that due to regulations impeding the flow of information, conflicted analysis may provide useful positive inside information to investors. Spindler (2006) adds to this argument that conflicted analysis can mitigate agency costs between underwriter and issuer, and may also encourage greater competition in the underwriting market if the 'quid pro quos' provided to analysts are competitively determined. In both articles, Spindler argues that then current regulations were suboptimal, and that eliminating conflicted analysis would make matters (even) worse. These arguments cite industry sources suggesting that companies are dissuaded from providing (potentially helpful) forecasts of their future performance due to fears of being sued under strict liability regulations if those forecasts inadvertently prove inaccurate; however, there is no

\footnotetext{
${ }^{25}$ Equities and equity funds are of particular importance to IRA investors. The ICI Study estimates that at the end of 2007 equity holdings accounted for $66 \%$ of assets held in traditional IRAs (Investment Company Institute 2011a).
} 
empirical evidence cited that attempts to quantify the costs to society from this chilling of information flow, or any comparison with the costs accruing to investors due to conflicted advice.

\section{Empirical Evidence}

Securities analysts are widely recognized as excessively optimistic. ${ }^{26}$ In an early work, Womack (1996) found analysts at major U.S. brokerage firms were seven times more likely to issue a new buy recommendation than a new sell recommendation. The problem of bias is particularly acute among sell-side analysts. Groysberg, et al. (2013) found that the buy recommendations by sell-side analysts underperformed buy recommendations from buy-side analysts by 5.8 percent. Additional research has found similar results, predominantly relying on data prior to regulations introduced during the early 2000s that attempt to reduce analyst bias. Analysts may produce overly favorable reports because of investment banking relationships (Ljungqvist et al., 2007; Chan et al., 2007; Kolansinski and Kothari, 2008; Agrawal and Chen, 2012; Casey, 2013), career concerns (Hong and Kubik, 2003; Ertimur, Muslu, and Zhang, 2011; Boudry, Kallberg, and Liu, 2013), parent company and subsidiary relationships (Lee, 2013), the desire to obtain better access to management's private information (Ke and Yu, 2006; Libby et al., 2008), because they receive and fear losing favors from firm executives (Westphal and Clement, 2008), mutual fund affiliation (Mola and Guidolin, 2009; Firth, et al., 2013), personal stock ownership (Johnston, 2013), because they are providing advice to many unidentified customers (Sah and Loewenstein, 2012), or purely psychological reasons (Willis, 2001; Hales, 2007). International studies suggest these conflicts of interest may be particularly acute in the U.S. (Ryan and Taffler, 2006). While bias in analyst reports appears to be pervasive, it can be mitigated by reputation concerns (Fang and Yasuda, 2009; Wang, 2009 ; Bradley, Clarke, and Cooney, 2012), competition (Sette, 2011; Hong and Kacperczyk, 2010), the presence of independent analysts (Gu and Xue, 2008j), the ability of the market to adjust for the bias (Karamanou, 2011), or the presence of institutional investor owners (Ljungqvist et al., 2007; Gu, Li, and Yang, 2013). Ability may also be a mitigating factor, as Cao and Kohlbeck (2011) find that analysts of particularly high skill and good reputation are less likely to issue overly optimistic recommendations or overreact to news.

The literature produces mixed results on the effect of analyst bias on investors. While much of the literature finds analyst conflicts of interest don't have a systematic impact on investors (see Mehran and Stulz (2007) for an overview or Agrawal and Chen (2008) for a specific example), many studies find that investors are adversely affected. Michaely and Womack (1999) present

\footnotetext{
${ }^{26}$ While the literature as a whole tends to conclude analysts provide biased reports, several studies find no evidence of bias. See for example, Bajari and Krainer (2004) and Clarke et al. (2006).
} 
evidence that the market does not fully account for analyst bias. Stocks that underwriter analysts recommend perform more poorly than 'buy' recommendations by unaffiliated brokers. The authors estimate the mean excess return for IPOs recommended by underwriter analysts is $-18 \%$ after 2 years, compared with $+45 \%$ for recommendations made by unaffiliated brokers. Barber et al. (2007) finds that over February 1996 - June 2003, buy recommendations from independent research firms outperform those from investment banks by roughly $8 \%$ on an annualized basis. Investment bank hold/sell recommendations however, outperformed those from independent firms by approximately $4.5 \%$, consistent with investment bank recommendations being positively biased so that sell recommendations contain more information. However, Casey (2013) found a larger market reaction to changes in recommendations from investment bank analysts in both directions than to those from independent research firms. Further evidence of bias in investment bank recommendations as opposed to independent firms has been found in European countries (see, for example, Bessler and Stanzel, 2009).

Perhaps more importantly, papers that differentiate the effects on institutional and retail investors tend to find individuals are less aware than institutional investors of bias and more susceptible to it. Cheng, Liu, and Qian (2006) present evidence suggesting institutional investors (fund managers) are more likely to rely on buy-side (in-house) analysts than potentially conflicted sell-side analysts. Malmendier and Shanthikumar (2007) find that large traders (a proxy for institutional investors) adjust their trading response downwards to analyst reports, but small traders (a proxy for retail investors) follow advice literally, suggesting individuals may be naïve about bias and place too much faith in advisors. The authors don't have access to individual trading strategies (e.g., how long securities are held) and cannot conclusively determine if small investors are harmed, but show that a naïve investment strategy of faithfully following analyst recommendations produces negative abnormal returns for a buy-and-hold strategy. Kelly et al. (2012) presents evidence from an experiment with retail investors in Singapore suggesting that investors are influenced by analysts' recommendations and that warnings about bias only partially influence a recommendation's impact. Baker and Dumont (2014) analyze the performance of "buy" and "hold" ratings and survey retail investors about their reliance on analyst recommendations. The authors find that "buy" ratings significantly underperform "hold" ratings, but that retail investors rely on these recommendations with making investment decisions.

Mikhail, Walther, and Willis (2007) also use trade size to distinguish between large ("sophisticated") and small ("unsophisticated") investors and finds that large investors respond more to the information contained in recommendation revisions, while small investors respond more to the occurrence of a recommendation and trade more in response to upgrades and 
buys. As a result, the authors find that in the five days following recommendation revisions, large traders earn an average raw return of $5.1 \%$, while small traders earn $-1.8 \%$.

De Franco, Lu, and Vasvari (2007) examine 50 events in which analysts were discovered ex-post to have issued misleading reports and find small investors were differentially impacted. Small traders (a proxy for individual investors) lost $\$ 2.2$ billion, two-and-a-half times as much as large traders (a proxy for institutional investors). While this paper provides some evidence on how misleading analyst behavior can impact individual investors, the sample of misleading reports analyzed may include only or a disproportionate number of the most extreme instances, which would greatly limit generalizability.

\section{Summary}

A substantial body of empirical evidence suggests analysts (particularly sell-side analysts) were excessively optimistic prior to regulation in the early 2000 s seeking to curb conflicts of interest. The literature, however, has produced mixed results on whether analyst biases have negatively affected investors. Much of the literature finds investors weren't systematically impacted (Mehran and Stulz, 2007; Agrawal and Chen, 2008). Other works (Michaely and Womack, 1999; Barber, Lehavy, and Trueman, 2007) have found that conflicted analysts' positive bias is associated with inferior returns.

However, studies that have attempted to compare the impacts of analyst bias on retail and institutional investors have generally found that individual investors were more acutely impacted. In particular, retail investors are more likely to follow recommendations literally (Malmendier and Shanthikumar, 2007) and more likely to trade in response to recommendation upgrades and 'buys' (Mikhail, Walther, and Willis, 2007). Both behaviors were found to likely to reduce returns.

3) Agency problems in mutual fund management

In addition to advice and analysis subject to conflict of interest, which may lead investors to invest in the wrong portfolio of products, there is possible conflicted behavior in mutual fund management that may damage investors' interests after investments have been made. ${ }^{27}$

Mahoney (2004) discusses a range of areas in which the incentives of mutual fund managers may be in conflict with mutual fund investors. Mutual fund managers generally have an incentive to maximize the size of the assets in their fund, leading them to use some fund assets for marketing, and entering into other relationships (e.g., with brokers) that siphon off some

\footnotetext{
${ }^{27}$ The conflicts of interest present in mutual fund management are of particular importance to IRA investors. At the end of 2010 mutual funds comprised 47\% of IRA assets, accounting for over \$2.2 trillion (Investment Company Institute, 2011a).
} 
value from the fund in order to attract new investors. While price competition could allow investors to vote with their feet, the expenses are not always obvious, and the noise in mutual fund returns makes it difficult to assess performance. Another issue in mutual funds, brought to the fore in the scandals in 2003, concerns 'market timing' practices, whereby some investors in a mutual fund make relatively rapid trades in and out of the fund, taking advantage of 'stale' prices, allowing some favored investors to profit at the expense of other shareholders. ${ }^{28}$ This practice was deemed not to be illegal if rapid trading was not prohibited in the mutual fund prospectus, but has a negative impact on long-term shareholders. As noted in GAO (2004a), these practices in mutual funds may have done significant damage to pension plans, estimating that 21 percent of pension fund assets at the time were invested in mutual funds. The same report mentions that pension plans would face some complications under SEC proposed regulations prohibiting late trading ${ }^{29}$, as well as generally facing some compliance cost passed on by fund managers. (See also GAO, 2004c for GAO assessments of regulatory reform efforts.)

Tkac (2004) describes some additional principal-agent issues in mutual-fund management: managers may not only fail to maximize expected returns for all their investors (as described above), but they may also fail to properly serve the risk-reward preferences of their investors, by pursuing risk-neutral strategies on behalf of risk-averse clients - on average, this strategy is likely to maximize total assets under management (and thus fees) for the manager, but exposes the client to more risk than they want. This may be further exacerbated by exploitation of investor 'style' preferences - in order to make a decision about which fund to invest in, investors may choose to limit their choice to choosing within a specific style of fund ${ }^{30}$ that they believe suits their risk-reward preferences, and pick the one with best returns; this gives fund managers an incentive to represent themselves as a particular style of fund but pursue riskier strategies in order to get higher returns than their competitors in the same style category. Nevertheless, Tkac's main thesis appears to be that in the free market, the aggregated demand of investors can "decide which risks are worth monitoring more aggressively and which, while present, are not worth their time and energy", and that the costs of regulator-mandated disclosure would outweigh any benefits. This thesis is based on the premise that if the investors

\footnotetext{
${ }^{28}$ Unlike normal stock prices, which update minute-by-minute as buy and sell orders come in, mutual fund asset values are calculated once (typically at the end of the New York trading day) and orders are filled based on that value. In some cases, it may be known that a price does not reflect all information - e.g., if a mutual fund invests in foreign stocks whose trading closes prior to the close in New York, then the price of those stocks for calculating mutual fund values may be out of date if relevant news has been released after the close of the foreign market. This gives rise to short-term arbitrage opportunities which can dilute the value of shares owned by long-term investors.

${ }^{29}$ Specifically, individuals wishing to take a loan from their defined contribution plan were generally able to do so based on the price at the end of the day, and thus get the exact value they wanted; insisting that a sharedenominated loan be requested prior to the close of trading could lead to an incorrectly-sized loan, and possibly violate pension plan rules if it exceeded permissible limits.

${ }^{30} \mathrm{Tkac}^{\prime} \mathrm{s}$ examples are growth funds and small-cap value funds.
} 
valued particular information more than it cost fund managers to provide the information, investors would already be paying managers to provide it, and moving their money from funds without disclosure to funds that provide disclosure. However, the evidence cited for this (e.g., that companies such as Morningstar have voluntarily increased disclosure in some areas of interest, and that companies associated with market timing scandals lost large amounts of business) is not conclusive.

The principal-agent issues facing mutual fund investors are challenging: it is impossible to observe effort made by mutual fund managers to gather information, and difficult to motivate the manager to use that information to reflect investor risk preferences. Stoughton (1993) and $\mathrm{Li}$ and Tiwari (2009) both note that linear contracts may not induce optimal behavior by analysts/managers, and suggest that non-linear contracts might be helpful; Li and Tiwari suggest that in the context of fund management, an additional non-symmetric incentive may be important (i.e., bonuses payable for exceeding some target, with no corresponding penalty for failing to reach a target). However, mutual fund regulations do not permit non-symmetric performance fees.

Different levels of market discipline may characterize different financial products. Evans and Fahlenbrach (2007) compare variable annuities with mutual funds, and find that variable annuity investors do not react so forcefully to poor performance as mutual fund investors; the lesser role of market discipline for the former may make traditional governance structures more relevant to variable annuities. The authors go on to show that conflicts of interest on some variable annuity boards lead them to make different decisions on how to deal with poorly performing sub-accounts than independent boards would, treating affiliated and non-affiliated sub-accounts differently when deciding which accounts to keep or replace.

Pension funds and municipal boards can face similar issues and problems. Pension funds which hold trillions of dollars in retirement savings - are often at risk for conflicted advice when they hire pension consultants: pension consultants help pension managers allocate assets and choose money managers, but those consultants may have incentives to recommend money managers who provide brokerage business to the consultant's firm, or may sell advice to money managers on how to secure business from pension funds (Revell, 2002). Public pension funds are more likely to employ pension consultants than corporate pension funds ${ }^{31}$, and so may be particularly vulnerable. For example, the City of Nashville received a \$10 million settlement from UBS PaineWebber after alleging that PaineWebber had deliberately misled the fund's board in order to generate additional brokerage fees (Weinberg, 2004). Some commentators have argued that SEC action is necessary, but that pension plan sponsors are also to blame for not demanding disclosure from their consultants ("SEC Examines Pay-to-play," 2004)

\footnotetext{
${ }^{31}$ In 2004, 80\% of public pension funds used consultants, vs. 41\% of corporate funds (Weinberg (2004))
} 
Municipal boards are another public entity that may be victim to conflicts of interest when making significant financial decisions. Doty (2010) describes widespread conflicts where municipal issuers are given advice by people who have financial relationships with dealers or were being paid contingent fees, and the specific examples of school districts in Tennessee, Wisconsin and Pennsylvania that suffered large losses "after inducement to issue variable-rate demand obligation securities joined at the hip with interest rate swaps, or into borrowing to purchase credit default swaps." Doty takes particular issue with the practice of advisors building a relationship of trust with municipal boards, and then resigning in order to underwrite the securities - without having to fully disclose the nature of their incentives when serving as underwriter, and the potential consequences for the municipal board.

\section{Empirical Evidence}

Many studies have found that actively managed mutual funds underperform passive portfolios. For example, Elton et al. (1993) find funds with higher fees and turnover underperform funds with lower fees and turnover. A variety of institutional conflicts can contribute to this result including the incentive to shift fees onto unsuspecting consumers and a divergence in incentives between mutual fund management and shareholders. ${ }^{32}$ Importantly, competition alone may not be sufficient to prevent disproportionately large fees, particularly for multiple class funds. Adams et al. (2012) find that despite heavy competition, funds managed by public sponsors charge approximately 28 basis points more in total fee spreads than their private counterparts.

Siggelkow (1999) finds mutual fund providers shift advertising and distribution fees to shareholders through 12b-1 fees. Accordingly, bond funds with $12 b-1$ fees are more risky than those without, despite having comparable returns. A one percentage point increase in $12 b-1$ fees is associated with a 0.1 point increase in the "best-fit" beta for the fund (determined using the index that generates the highest $R^{2}$ for the fund's return). The author also finds mutual fund providers shift part of their research expenses through soft dollars, without reducing explicit fees. Horan and Johnsen (2008) find premium commissions are positively related to riskadjusted performance, suggesting this soft dollar arrangement isn't necessarily unjust enrichment at the expense of the investor.

Beyond expense shifting, mutual fund investors may be exposed to other substantial fees they might not be aware of. Karceski, Livingston, and O'Neal et al. (2004) suggest mutual fund shareholders are subject to sizeable commissions as a result of portfolio trading in addition to

\footnotetext{
${ }^{32}$ Chen and Huang (2011) find that compensation policies designed to be consistent with fund performance are positively associated with fund return and negatively associated with portfolio turnover.
} 
implicit costs from bid-ask spreads. The authors estimate that brokerage commissions averaged 27 bp in 2001. ${ }^{33}$ Similarly, Livingston and O'Neal (1996) find that brokerage portfolio commissions were $21 \mathrm{bp}$ per year as a percentage of net assets over $1989-1993$. Since these fees are not incorporated in expense ratios, they can be difficult for the investor to observe. More recently, Edelen et al. (2007) estimate that trading costs (brokerage commissions, spreads, and price impact) are on average 144 bp per year, a figure comparable to average annual expense ratios (121 bp). The authors also find that trading is negatively related to returns for funds with relatively large trade size and may be partially motivated by soft dollars. Edelen et al. (2012) find that accounting for expenditures opaquely (through brokerage commission bundling) as opposed to transparently (through expensing) adversely impacts investors returns, but that opaque disclosure of costs has a less negative impact on flows, suggesting obfuscation can be effective in hiding payments for distributions.

Ferris and Yan (2007) find that namesake funds (whose owners typically possess a relatively large share in the fund management company) have on average expense ratios $12-15 \mathrm{bp}$ higher than those of other equity funds, consistent with a conflict between fund management companies and shareholders. Chen, Kubik, and Hong (2013) find that mutual funds managed externally underperform those managed internally by 50 - 72 bp per year. The authors argue that in order to extract performance, externally managed funds are given higher-powered incentives and take less risk as a result. Berzins et al. (2013) find that asset management business owned by investment banks earns risk adjusted returns 46 basis points lower than portfolios owned by non-bank conglomerates, suggesting conflicts of interests present in investment banks impair investor performance. Pool et al. (2013) find evidence that mutual fund families acting as trustees of $401(\mathrm{k})$ plans exhibit a strong preference for their own funds despite their fiduciary duty. Trustees are more likely to keep and recommend affiliated funds even if those funds appear in the lowest decile of fund performance. The study found that these poor performing affiliated funds underperform by an average of $3.6 \%$ annually on a riskadjusted basis.

Chen, Yao, and Yu (2007) examine the performance of actively managed equity mutual funds and find those managed by insurance companies underperform non-insurance funds by 1.6 percentage points per year on average. The authors argue that this underperformance is driven insurance companies' cross-selling efforts, often to unsophisticated, less performance sensitive investors. Hao and Yan (2012) find evidence that investment bank affiliated mutual funds perform worse that unaffiliated funds, consistent with the hypothesis that underwriting and other lines of business create a conflict of interest that harms investors.

\footnotetext{
${ }^{33}$ The authors note that due to difficulty in obtaining the necessary data, the estimate is only preliminary.
} 
Pension funds, as previously mentioned, are also vulnerable to conflicts of interest. Coleman, Esho, and Wong (2006) examines agency arrangements in pension funds in Australia and finds that the median for-profit retail fund reports return on assets that are $228-318$ bp lower per year than the median for not-for-profit funds. The authors interpret this as consistent with potential conflicts of interest among board members of for-profit funds. A 2007 GAO study found that pension consultants identified as having undisclosed conflicts of interest were associated with lower plan returns on the order of 1.3 percentage points annually (GAO, 2007). The sample of consultants included, however, was both small and previously identified and selected in a non-random fashion by the SEC, raising questions about the generalizability of the results.

\section{Summary}

An extensive body of empirical work finds numerous agency problems in mutual fund management. Actively managed funds are frequently found to underperform comparable passively managed funds (see for example Elton et al., 1993). Mutual fund holders are often exposed to sizeable trading costs generally (Edelen, Evans, and Kadlec, 2007) and brokerage commissions specifically (Livingston and O'Neal, 1996). ${ }^{34}$ Mutual fund owners with relatively large shares in a fund's management company (e.g., namesake funds) are found to have higher expense ratios (Ferris and Yan, 2007). Further, mutual funds managed externally (Chen, Kubik, Hong, 2011) or by insurance companies (Chen, Yao, and Yu, 2007) may deliver investors inferior returns. Given Americans' low levels of financial literacy, it is doubtful that many investors are fully aware of these costs.

\section{4) Survey and experimental data ${ }^{35}$}

Given the difficulties in observing and empirically linking advice to behavioral changes, surveys and experiments may provide additional insight into how conflicted advice impacts investors.

Chater, Huck, and Inderst (2010) conduct online experiments with over 6000 subjects across Europe on willingness to pay and follow advice from financial advisors. They find that, even though the advisors' compensation scheme is disclosed, subjects display the same willingness to pay and follow advice regardless of whether the advisor's compensation scheme presents a potential conflict of advice.

\footnotetext{
${ }^{34}$ Horan and Johnsen (2008) find that soft dollar arrangements may not necessarily be detrimental.

${ }^{35}$ This section presents survey and experimental evidence not discussed elsewhere in our review. The next section discusses experimental evidence suggesting that disclosure may not mitigate conflicts of interest but may, in fact, exacerbate them.
} 
Popova (2010) experimentally investigates whether complementing commissions with transfers from the advisee to the advisor prior to receiving advice can mitigate a financial advisor's conflict of interest and induce better recommendations. Employing a sample of 254 German undergraduate students, the study suggests that mandatory transfers (essentially fees for advice) are ineffective in reducing conflicts of interest created by commissions, but voluntary payments (essentially gifts designed to create a moral obligation) provided before advice is issued increase truthful reporting.

Similarly, Angelova and Regner (2013) also use a sample of German undergraduate students to investigate whether voluntary payments and reciprocity can mitigate conflicts of interest and induce truthful reporting. Using a three stage design, the authors find that clients are frequently willing to pay for advice and that voluntary upfront payments induce more truthful reporting on the part of advisors, particularly when there is also an opportunity for the client to provide an additional voluntary payment to the advisor after observing the experimental outcome.

Chang and Ng (2008) conduct an experiment with 67 students in finance/accounting classes at an Australian university to examine the comparative influence of management and analyst forecasts. Subjects were typically concerned about conflicts of interest on the part of management and found analyst reports to be more credible. Additionally, the students were more likely to take negative news more seriously, perhaps because they ran counter to expectations and thus delivered stronger signals.

Beyer et al. (2013) experimentally examines whether advisor incentives influence purchasing decisions. Participants (students, staff and alumni at a university in the UK) were entered into a lottery for an electronic device and were given the opportunity to purchase insurance for the product should they win the raffle. Advisors were randomly assigned incentives, some receiving payment when the client chose to insure and others receiving payment when the client chose to forgo insurance. Although advisors were required to describe the insurance truthfully, clients assigned to an advisor incentivized to induce insurance purchase were roughly twice as likely to insure.

While the experiments just described provide some insight into how people perceive and respond to conflicts of interest, they all rely on relatively small samples comprised entirely of students $^{36}$. In contrast, Hung and Yoong (2010) conduct a hypothetical choice experiment (with a much larger and more representative sample) investigating how financial advice impacts investment behavior. The authors find that unsolicited advice has no observable effect on

\footnotetext{
${ }^{36}$ The sample in Beyer et al. (2013) also included university staff and alumni, but the proportions of these participants are not provided.
} 
behavior, but individuals who solicit advice ultimately improve performance, despite negative selection on financial ability. Importantly however, the advice offered to respondents was unbiased, removing any impacts of conflicts of interest.

Relatedly, Bhattacharya et al. (2012) conduct a field experiment with clients of a large German bank randomly offering 8,000 people unbiased financial advice on how to improve the efficiency of their portfolios. The authors find that few people (5\%) accepted the offer of free unbiased advice, and those who received the advice rarely followed it. Further, investors who need the advice most are least likely to receive it.

Danilov et al. (2013) examine the impact of team incentive schemes on quality of advice with a sample of professionals from the German financial services sector. Advisors are given incentives to recommend lower quality financial products. The authors find that when a team is closely affiliated, team incentives induce more biased recommendations than individual incentives.

Survey data can be particularly valuable in determining who relies on financial advisors and what benefits they impart.

A 2010 PLANSPONSOR survey of 5,929 defined contribution plan sponsors and clients revealed that over time employees have received increased access to financial advisors, with more than $75 \%$ of sponsors claiming to offer some form of financial investment advice at the time of survey. Additionally, the number of investment options provided by the respondents' plans rose approximately 10\% from 2009 to 21.4 investments products on average in 2010, potentially increasing the need for a financial advisor for many employees.

A 2011 Transamerica survey of 4,080 workers revealed that approximately one third of respondents claimed to rely on a financial advisor to help them manage their retirement savings and investments. Moreover, 23\% reported allocating their assets based on what their advisors recommended.

Bluethgen, Meyer, and Hackethal (2008) survey 64 independent financial advisors in Germany and find that $77 \%$ of respondents prefer recommending an actively managed fund to a passively managed fund, similar to the findings of Mullainathan, Noeth, and Schoar (2010). The authors also find that advisors who are both sophisticated and receive a smaller portion of their income through commissions are more likely to recommend passive index fund investments. ${ }^{37}$ Endogenous choice of compensation schemes, however, may be influencing the latter result.

\footnotetext{
${ }^{37}$ As previously discussed, Cumming, Johan, and Li (2011) suggest investors in the German stock exchange are less well protected from broker conflicts of interest than investors in US markets.
} 
Georgarakos and Inderst (2012) examine household surveys from 15 European countries and find that trust in financial advice is a key component in households' willingness to hold risky assets, particularly when their self-perceived financial capability is low. Guiso, Sapienza, and Zingales (2008) survey 1,834 customers of an Italian bank and find that those that place a high level of trust in bank officials/brokers are more likely (by 16 percentage points) to invest in stocks. ${ }^{38}$ Von Gaudecker (2011) examines a Dutch household survey and finds that low numerical-financial skills and not seeking advice are associated with losses from underdiversification. $^{39}$

Calcagno and Monticone (2014) examine the ability of financial advisors to compensate for low financial literacy by examining how financial capability influences reliance on professional advice. Using a survey of 1,686 customers from a large Italian commercial bank with at least 10,000 euro in their account, the authors find that financial literacy increases the probability of consulting a financial advisor relative to delegating decisions to an advisor or going it alone. Interestingly, the effect of financial literacy on dependency upon advice appears to be nonmonotonic; higher financial literacy reduces the probability of delegating financial decisions to an advisor, but also reduces the probability of investing autonomously.

\section{Summary}

Evidence from surveys and experiments suggests US investors frequently rely on financial advisors (Transamerica, 2011), are faced with increasingly complex financial decisions (PLANSPONSOR (2010)), and may improve performance when soliciting advice from an unbiased advisor (Hung and Yoong, 2010). International evidence suggests investors are more willing to hold risky assets when they place a high level of trust in brokers (Guiso, Sapienza, and Zingales, 2008)) and when self-perceived financial capability is low (Georgarakos and Inderst, 2011). Further, international investors who have low numerical-financial skills and do not seek advice may be more likely to hold underdiversified portfolios (Von Gaudecker, 2011). Unfortunately, investors with low financial literacy may also be less likely to consult an advisor (Calcagno and Monticone, 2014).

Given the increasing complexity of financial decisions facing individuals in the US, financial advisors could provide investors with a valuable service. However, as noted in previous

\footnotetext{
${ }^{38}$ Investors in European exchanges are generally less well protected by explicit stock exchange rules targeting broker-agency conflicts of interest than investors in US markets (Cumming et al., 2011). In Italy, Cumming et al. (2011) find there are no explicit rules protecting investors from improper execution or preventing brokerages from executing trades that do not fit within their clients' interests.

${ }^{39}$ In the Netherlands, the Authority for Financial Markets requires financial service providers to provide customers with specific information about the product being sold; including information about how much compensation the advisor receives (http://www.afm.nl/en/consumer/vertrouwen/informatieplicht.aspx).
} 
sections, while financial advisors do appear to provide investors many intangible benefits, there is little evidence linking brokers to superior returns.

\section{5) Regulation and Disclosure}

Both regulators and market participants recognize that conflicts of interest can have material impacts upon investors. In many of the preceding examples of conflict of interest, the ability of a financial service provider to act on their conflicted interest without being punished by investors is tied to a lack of transparency on costs and actions, and potentially an inability of investors to use the information they do have to make optimal decisions. Disclosure and formal regulation are often suggested remedies. This section of the review examines studies addressing the effectiveness of both types of intervention.

\section{i) Regulation}

In response to perceived conflicts of interest surrounding analyst reports, the SEC enacted Regulation Fair Disclosure (Reg FD) in 2000. Reg FD prevents management from disclosing material information only to selected analysts, reducing the incentive for analysts to bias reports in order try to gain access to privileged information. Subsequently, the SEC accepted NASD Rule 2711, NYSE Rule 472, and the Global Research Analyst Settlement in late 2002 and 2003. Generally, these regulations further address analysts' conflicts of interest and limit information transmission between analysts and banks' investment banking branches.

The literature has generally found that the regulations have reduced, but not eliminated, the amount of conflict present in analyst recommendations. ${ }^{40}$ Chih-Ying and Chen (2009) examine the impact of NASD Rule 2711 on analyst independence and find a significantly stronger relationship between recommendations and intrinsic value estimates (analyst's earnings forecasts relative to stock prices) after the Rule came into effect. Correspondingly, the authors find a weaker relationship between stock recommendations and conflicts of interest (net external financing and amount of underwriting business) after implementation of the Rule. Further, stock recommendations issued by analysts with greater potential conflicts of interest were found to experience a greater increase in the relation with intrinsic value estimates after regulation.

\footnotetext{
${ }^{40}$ Dubois, Fresard and Dumontier (2014) find that the Market Abuse Directive (MAD) implemented across European Countries had similar effects. After implementation, the distribution of recommendations issued by conflicted brokers is much less skewed towards positive recommendations. Among conflicted brokers, the proportion of "Buy" and "Strong Buy" decreased 51\%. The authors also found that the effect of MAD is significantly stronger in countries where MAD's sanctions are the strongest.
} 
Ertimur et al. (2007) compares analyst reports issued prior to Reg FD with reports issued after the Global Settlement and finds that regulation improved the integrity of 'buy' and 'hold' recommendations. Specifically, the authors find that regulation increased the relation between earnings forecast accuracy and recommendation profitability for 'buy' recommendations, particularly for analysts expected to be the most conflicted. In addition, the authors find that treating 'hold' recommendations as 'sell's results in significantly negative mean abnormal returns after regulation, in contrast to the positive returns earned from such a recommendation strategy prior to Reg FD.

Kadan et al. (2009) find that conflicts of interest (past presence of an underwriting relationship between the brokerage house and firm being recommended) were an important determinant of stock recommendations prior to regulation. After regulation, however, the distribution of analyst reports became more balanced and less optimistic, better reflecting the literal meaning of the recommendations; ${ }^{41}$ conflicted analysts were no longer more likely to issue optimistic recommendations than unaffiliated analysts, but were still less likely to issue pessimistic recommendations.

Lach, Highfield, and Treanor (2012) also find a reduction in the amount of positive bias contained in analyst reports after regulation by examining the long run performance of analyst ratings of IPOs at quiet period expiration following the implementation of NYSE Rule 427 and NASD Rule 2711. The authors find recommendations can now be taken at closer to face value, with 'buy' recommendations outperforming 'hold' recommendations, and that the strength of analyst coverage (number of 'buy' recommendations) can predict future returns.

Barniv et al. (2009) find that the regulations have tightened the relationship between residual income valuations and analyst recommendations and increased the usefulness of earnings forecasts to investors. The negative relation between stock recommendation and residual income valuations diminishes after Reg FD and becomes positive after other regulation (NASD Rule 2711, NYSE Rule 472, Global Research Analyst Settlement). Further, residual income valuations have an increasingly positive relationship with future returns after the adoption of Reg FD. However, the authors also find that a negative relationship between stock recommendations and future returns still persists, but has diminished after the regulations subsequent to Reg FD.

In response to concerns about the impacts of conflicts of interest in the retail financial advice market, several countries have recently banned commissions. For example, in December 2012 the United Kingdom's Financial Services Authority (now Financial Conduct Authority (FCA))

\footnotetext{
${ }^{41}$ Although the distribution of recommendations became more balanced, the authors note that many brokers moved from a five-tier recommendation system to a three-tier system and recommendations were, on balance, less informative.
} 
Retail Distribution Review (RDR) issued new rules under which financial advisors are no longer allowed to charge commissions for their services, requiring them to bill hourly instead. ${ }^{42}$ Australia's Future of Financial Advice Reforms, which became mandatory in July 2013, contained several provisions restricting compensation for advice including a ban on commissions for new sales of financial products (except life insurance) and an "opt-in" clause which requires financial advisors to receive agreement every two years from clients for ongoing advice fees along with disclosure of those fees each year.

While there has been limited rigorous research on the impacts of these bans due to their recency, ${ }^{43}$ some early analysis has been conducted, particularly regarding the bans' implementation. The FCA has completed two of its planned three thematic reviews examining how well firms are implementing the RDR. The first review surveyed 50 firms and found that, generally, firms had acted to implement the new requirements, yet some firms were not providing clients with some or all charges in cash terms (as opposed to percentages) and that some firms were not clear about what ongoing services would be provided to clients' in exchange for ongoing fees (FCA, 2013a). The second review surveyed 113 firms to examine whether they offered independent advice. ${ }^{44}$ Of the 88 firms who claimed to offer independent advice, the FCA determined that 8 firms were in fact not acting independently and had concerns that another 11 firms may not be meeting requirements (FCA, 2014). ${ }^{45}$

Survey evidence on the impact of the RDR presents a mixed picture. A survey of 250 financial advisers conducted by NMG Consulting found that $47 \%$ had recently turned away clients on the basis that the cost of their service had become disproportionately high for some clients' needs. ${ }^{46}$ However, research conducted by the Association of Professional Financial Advisers (AFPA) found that only $12 \%$ of advisers increased their hourly rate following the implementation of the RDR. ${ }^{47}$ A survey commissioned by the UK's Department for Work and Pensions found that the use of commission-based advisers for contract-based defined

\footnotetext{
42 The new rules will affect an estimated 21,700 independent financial advisers offering guidance on pensions, unit trusts, and individual savings accounts. http://www.theguardian.com/business/2012/dec/30/fsa-ban-commissionselling-death

${ }^{43}$ Other commentators have suggested there has been a reduction in the level of initial charges following the RDR, but an increase in the level of ongoing charges. http://www.moneymarketing.co.uk/opinion/how-advisercharging-is-shaping-up-post-rdr/2002493.article

${ }^{44}$ An independent adviser is able to recommend all types of retail investment products from all firms across the market, while a restricted adviser can only recommend certain products, providers, or both.

${ }^{45}$ In a separate review of life insurers and advisory firms, the FCA found numerous examples of life insurers paying benefits to advisory firms, that while not commissions, appeared to be linked to securing sales or distribution, violating the spirit of the RDR (FCA, 2013b).

${ }^{46}$ http://www.moneymarketing.co.uk/news-and-analysis/advisers/apfa-research-half-of-advisers-have-turnedaway-clients-post-rdr/2004093.article

${ }^{47}$ It is possible that some advisers increased their hourly rates in anticipation of RDR implementation, however. http://www.apfa.net/news/press.php?id=353
} 
contribution schemes increased from $28 \%$ in 2011 to $41 \%$ in 2013, possibly in response to the looming RDR (Department for Work and Pensions, 2014). ${ }^{48}$ Another NMG Consulting survey of 1,000 investors and 350 advisers found that while many banks withdrew from the retail advice market, there was only a small decline in the number of advisers from independently owned firms. Additionally, the study found evidence that firms were thriving under the RDR, with an average increase in income of $5 \%$ among firms in their sample. ${ }^{49}$ In all cases, however, there is limited information about the sampling frame or representativeness of the surveys, limiting the insights that can be drawn.

\section{ii) Disclosure}

In principle, disclosure can increase investor awareness of conflicts of interest, potentially mitigating their impacts. However, recent research and numerous commentaries ${ }^{50}$ argue that disclosure in isolation may not improve investors' outcomes.

Haslem (2006) explains the way in which readily-disclosed fees in the mutual fund industry do not necessarily reflect the true costs associated with the fund. Managerial fees are included in the benchmark 'expense ratio', but other costs to the fund, including brokerage commissions and some other implicit costs of trading ${ }^{51}$, are not included. Haslem argues that reasonable estimates for these additional costs, using portfolio turnover to calculate expected values for the 'other' costs, would give a potentially more useful 'total expense ratio'; he shows how Vanguard's 500 Index fund (with relatively high rate of return and comparatively low turnover) performs particularly well when comparing its rate of return with its total expense ratio. He argues that higher total expense ratios of other funds should seem unreasonable to investors unless they are producing significantly higher returns, which is rare. Similar points were raised in a report by Zero Alpha Group (described in "Analysis Finds Fees Disclosed," 2004), showing that the highest turnover funds may have hidden trading costs that are more than twice as high as published expense ratios, and that passively managed index funds (with low turnover and fees) will often outperform actively managed funds. For a sample of 10 high-turnover funds, the implicit trading costs averaged 1.91\%; in one of the most egregious cases, the PBHG Large Cap

\footnotetext{
${ }^{48}$ The RDR specifies that new products sold since December 31, 2012 may not be sold on a commission basis, but commission can continue on products sold prior to 2013.

${ }^{49}$ http://citywire.co.uk/new-model-adviser/news/the-results-are-in-which-rdr-predictions-provedtrue/a720262? section=new-model-adviser\#i=1

${ }^{50}$ See, for example, Frankel (2013).

${ }^{51}$ In particular, Haslem draws attention to the effect of bid-ask spreads in trading - if the 'true' value of a particular asset is the midpoint between the bid and ask prices, then the distance between the trade price and that midpoint is an implicit cost of trading
} 
Fund had an estimated implicit cost (due to turnover) of $4.27 \%$ and brokerage commissions of $3.16 \%$, while publishing an expense ratio of only $1.16 \%$.

A series of GAO reports and testimony in front of the House and Senate noted that disclosures pertaining to mutual funds often exceed those provided for other financial products, and acknowledged that additional disclosure would incur additional costs; but nevertheless, increased transparency is necessary if investors are to understand the potential conflicts of interest that their financial advisors face, and be able to make informed decisions about how to invest their money, particularly when facing complex and changing schedules of fees; and more transparency could promote greater price competition in the industry (GAO, 2000; GAO, 2003c; GAO, 2003b; GAO, 2004b). GAO recommended further regulatory action by the SEC on mutual funds, though some in the industry and press expressed concern about potential overregulation (if some reforms created costs without clear benefits) and unequal treatment of mutual funds compared with other financial instruments ("A Rash of Rules," 2004).

While mandatory disclosure could provide (at some cost) a greater amount of information and transparency for investors, this may not be a full solution if investors do not understand or use this information correctly. As discussed elsewhere, Tkac (2004) believes that a lack of voluntary disclosure in the mutual fund industry may be a sign that investors do not value the information enough to be willing to pay for it. Palmiter and Taha (2008) survey academic literature and find that investors do not have a grasp of the data available to them, paying insufficient attention to data on expenses, risk profiles and basic characteristics of funds, and instead focus most of their attention on historical rates of return (a strategy for which there is minimal empirical support). They conclude that disclosure may not be enough, and that regulators should pay more attention to research on the characteristics and capabilities of investors when formulating policy. A study conducted by the North American Securities Administrators Association (NASAA) found a wide disparity in how fees were disclosed and indicate that disclosures may lose their effectiveness when hidden in small print, incorporated in lengthy account opening documents, or opaque about the services provided (NASAA, 2014). ${ }^{52}$ Rennekamp (2012) finds that more readable disclosures lead to stronger reactions among small investors, increasing valuations more positively following good news and more negatively following bad news.

Inderst and Ottaviani (2012) build a theoretical model in which consumers receive advice about product suitability from intermediaries that receive hidden kickbacks from (financial) firms. The model suggests that disclosure (revelation of kickbacks) leads to a reduction in commissions, but may actually lower welfare if intermediaries are sufficiently concerned about the suitability of customer choices.

\footnotetext{
52 The study also found that in the outgoing transfer fees context, markups were routinely in the $100 \%$ to $280 \%$ range, perhaps in part due to consumer confusion about the fees being charged.
} 
Similarly, there is substantial evidence that many investors give no attention or cursory attention to the disclosed information available to them. Two surveys of $401(\mathrm{k})$ investors found that large numbers of plan participants fail to open their statements, ignore information provided to them, or spend very little time reading the information; this leads some to question whether additional disclosure is likely to be effective (Nash, 2009).

While typical 401(k) plan participants (and IRA investors) may lack the sophistication, motivation or attention to fully investigate information on plan fees (particularly if they have relatively small amounts invested), 401(k) plan sponsors have been found to be remarkably ignorant of fees, despite the potentially huge sums at stake. In one survey in the early 2000s, roughly half of sponsors did not know the fund expense ratios and investment management fees (“Advice from Whom?" 2001).

While there is some evidence that plan sponsors may have paid more attention to the major headline fee categories in recent years, when it comes to some of the more 'hidden' fees, more than half of sponsors in a 2006 survey did not know how much they were paying in broker/advisor compensation through their 12b-1 fees ("Plan Sponsors Poised," 2006). Plan sponsors may also be just as ignorant of conflicts of interest as plan participants, if they do not examine closely whether or not their financial advisors are truly independent ("Warning Signs Your 401(k) Adviser," 2008). As well as not having command of relevant information, 401(k) plan sponsors may not be doing enough to prepare employees to manage their resources, according to a recent survey of benefit directors (Ortman, 2011).

\section{Empirical Evidence}

Cain, Loewenstein, and Moore (2005) found that in an experimental setting disclosure can make advisors more comfortable in giving biased advice and may cause them to further inflate their recommendations. Investors in their experiment were made worse off as people generally don't discount biased advice sufficiently, even when a conflict of interest is disclosed. Gino, Brooks, and Shweitzer (2012) find that when people are anxious (e.g. facing an important investment decision) they are more likely to seek and rely on advice, but are worse at discerning bad advice and are more willing to take advice from an advisor with a disclosed conflict of interest. Loewenstein, Cain, and Sah (2011) review the literature on the unintended consequences of disclosure and finds disclosure can also increase the pressure on investors to comply with advice as a rejection of advice may insinuate corruption. In an experimental setting, Sah, Loewenstein and Cain (2013) find that with disclosure, advisees feel compelled to comply with advice because they feel responsible for their advisors' personal interests. In an accounting setting, Dopuch, King, and Schwartz (2003) found disclosure of non-audit services 
decreased the accuracy of participants' beliefs in the objectivity of auditors when independence in appearance was inconsistent with independence in actuality. In these treatment arms, prices deviated more from economic predictions than in the no disclosure framework, suggesting lower market efficiency.

Chater, Huck, and Inderest (2014) found, in an online experiment, that simply disclosing advisors' compensation schemes did not affect subjects' willingness to pay or follow advice from advisors with a potential conflict of advice. Including an explicit statement that the advisor's incentives might not be aligned with those of the advisee decreased willingness to pay for advice, but the vast majority of subjects still opted to pay for the potentially conflicted advice.

Although disclosure alone is not a panacea, it can be part of an effective mitigation strategy. Cain, Loewenstein, and Moore (2011) suggest that receiving unbiased advice in addition to (disclosed) biased advice can help ameliorate inadequate discounting of conflicted advice. ${ }^{53}$ Sah and Loewenstein (2014) find that when conflicts of interest are avoidable, disclosure (either mandatory or voluntary) can discourage advisors from accepting conflicts of interest, thereby improving the quality of provided advice. Church and Kuang (2009) found that in an experimental setting when the investor had the ability (at a cost) to penalize bad advice in conjunction with disclosure, advisors offered less biased advice and investor payoffs increased.

\section{Summary}

Regulation and disclosure are often recommended as interventions to mitigate problems caused by conflicts of interest. In response to bias contained in analyst reports, regulation has been credited with reducing the correlation between stock recommendations and investment bank conflicts of interest (Chih-Ying and Chen, 2009), improving the integrity of buy-hold recommendations (Ertimur, Sunder, and Sunder, 2007), shifting the distribution of recommendations from optimistic to more balanced (Kadan et al., 2009), reducing the amount of positive bias (Lach, Highfield, and Treanor, 2012), and increasing the usefulness of earnings forecasts to investors (Barniv et al., 2009). When carefully done, regulation can successfully mitigate conflicts of interest.

The empirical evidence on disclosure suggests that in isolation it may be ineffective and could actually exacerbate problems arising from conflicts of interest. Without other intervention, disclosure has been found to make advisors more comfortable in inflating their recommendations (Cain, Loewenstein, and Moore, 2005), increasing pressure on advisees to comply with advice (Loewenstein, Cain, Sah, 2011; Sah, Loewenstein and Cain, 2013), and

\footnotetext{
${ }^{53}$ Sah and Lowenstein (2011) find that participants do better when they receive an unconflicted second opinion, but also find that conflicted advisors further distort their recommendations when aware of competing advisors.
} 
confusing recipients when the information disclosed is not representative of objectivity (Dopuch, King, Schwartz, 2003). Additionally, people with low levels of financial literacy or who are anxious (Gino, Brooks, and Schweitzer, 2012) may not pay sufficient attention to the information that is disclosed.

However, disclosure can play an important role in a more comprehensive intervention strategy. When coupled with unbiased recommendations (Cain, Loewenstein, and Moore, 2011) or when recipients can penalize bad advice (Church and Kuang, 2009), disclosure can help improve investors' outcomes.

6) Bias in audits

Conflicts of interest may also impact employee ownership plan participants. Employee Stock Ownership Plans (ESOPs) have become an important component of many Americans' retirement portfolios. Approximately 10 million employees are covered by an ESOP and total assets owned by ESOPs was estimated to be $\$ 901$ billion at the end of 2007 (ESOP, undated). Private companies must have an annual outside valuation performed to determine the value of their shares. Given the prevalence and size of ESOP holdings, these valuations can have meaningful impacts on many Americans' retirement holdings.

When an ESOP appraiser is hired by the company whose worth he/she is evaluating, there is a potential conflict of interest if the appraiser wants to maintain a good business relationship with the company. A similar, albeit extreme, example can be found in residential real estate appraisals before the housing market crash. As cited by the Financial Crisis Inquiry Commission (2011), in 2006, 90\% of surveyed real estate appraisers felt pressure to inflate the value of homes they were appraising, and most of this pressure came from mortgage brokers. At that time, appraisers were typically hired by mortgage brokers.

An ESOP valuator that has a personal interest in the plan being audited or financial incentives that differ from those of the plan participants may produce a biased valuation. While there are few studies examining bias in ESOP valuations, there is a large literature examining how professional auditors may be biased by financial and non-financial considerations. In particular, the literature suggests auditors may be more willing to accept dubious company assumptions when conflicted.

Professional auditors are often compensated by the same firm they are auditing, creating a potential conflict of interest. Researchers have examined this possible conflict in terms of the total compensation received by the auditing firm, the length of the relationship, and the effect of low initial fees offered in the hopes of continued work with the client. In a pension plan context, Byrne et al. (2007) examine approximately 200 UK corporations and find that auditors approve the most favorable assumptions (e.g., high expected return on equity) when total audit 
fees are high. On the other hand, low audit fees may indicate a position of low bargaining power. For example, Asthana and Boone (2012) found that below normal fees were associated with lower audit quality, in terms of earnings forecasts and discretionary accruals.

In addition, an expectation of, or desire for, future business may give rise to biased audits. Deis and Giroux (1992) examine audits provided by small, independent CPA firms in Texas to independent school districts. The authors find evidence that audit quality (based on quality control review findings) declines as the length of auditor tenure increases, possibly because auditors lower standards to maintain business. In a study of United States-based firms audited by the four largest auditing agencies, Abdel-Meguid, Ahmed, and Duellman (2011) find that firms tend to report cash accruals aggressively when the auditor has a high economic dependence on the firm, where dependence is defined as the client's fees as a total of all fees earned by the auditor across all its clients.

Beeler and Hunton (2002) conduct an experiment with 73 audit partners from CPA firms and find evidence that "low-balling" (offering an initially discounted price in order to form a relationship which may be profitable in the future) heightens the desire to maintain a long-term relationship, potentially impairing auditor independence. Fatemi (2012) extends this experimental work to examine actual auditing consequences. In an experiment involving accounting undergraduate students, he finds auditors who gave a low introductory offer were less likely to audit riskier investments than auditors paid a flat fee. However, other works have suggested that "low-balling" does not impair independence and may actually improve it (Lee and Gu, 1998; DeAngelo, 1981).

The provision of non-audit services, which increase client specific revenue, may also adversely impact auditor independence. Auditors may produce positively biased reports in an attempt to maintain the auxiliary business. Frankel, Johnson, Nelson, 2002 find a positive relationship between non-audit services and earnings management. Kinney, Palmrose, and Scholz, 2004 find a positive association between unspecified non-audit services and poor quality audits (restatements of previously issued financial statements) in the United States, while Ahadiat (2011) corroborates this finding in the UK and Australia. Markelevich and Rosner (2013) find that fees for non-audit services are correlated with SEC sanction for fraud as a proxy for poor audit quality. Paterson and Valencia (2011) differentiate further among the types of services, and they find that repeated tax services actually improve audit quality, in terms of restatements, whereas one-time tax services and other non-audit services are associated with a decrease in audit quality. Further, Blay and Geiger (2013) find auditors issue fewer modifications to going concern statements when higher payments for non-audit services are made after the audit. However, other studies have failed to find evidence that non-audit 
services compromise auditor independence (see for example Antle et al., 2006; Ashbaugh, LaFond, and Mayhew, 2003; and Larcker and Richardson, 2004; Koh et al., 2013).

Some recent research has examined the effect of non-audit fees in different regulatory environments. Abdel-Meguid, Ahmad, and Duellman (2011) find that the association between reporting overly large accruals and the auditor's lack of independence did not continue after the Sarbanes-Oxley regulation took effect. Moreover, they also find no relationship between firm reporting and auditor dependence if there is strong non-auditing oversight by a board of directors or institutional investors even before the regulation. Similarly, Lim, Ding, and Charoenwong (2013) find that non-audit fees are associated with lower audit quality, as measured by current accruals, only in the absence of institutional oversight.

Several related papers give psychology-based insights into the failures of the accounting industry to provide reliably objective audits. Bazerman, Morgan, and Loewenstein (1997) report experimental evidence of self-serving bias leading people to unconsciously overvalue evidence that supports their position and downplay evidence against; and that close relationships developed over time between auditor and client can easily lead to the same types of unconscious bias in favor of the client in the present moment, at the expense of probable losses in the future for unknown investors. Bazerman, Loewenstein, and Moore (2002) and Moore et al. (2006) marshal some of the same evidence on unconscious self-serving bias; in addition, they describe evidence that individuals are likely to 'go along with' a more biased judgment than they would be to originate such a biased judgment themselves (a finding particularly relevant to auditors, who are charged with giving or withholding approval for financial reports generated by their clients, rather than generating their own reports). The authors also describe the process of 'escalation of commitment': in an ambiguous situation one year, an auditor may acquiesce to a slightly biased judgment that they decide is not worth disputing; the next year, they may be pushed slightly further, but the slight difference from the previous year also seems not worth disputing; eventually auditors may find themselves auditing clearly dubious accounts, but knowing that disputing them would reveal their own previous failures of judgment the auditor may, as a result, choose to help the client cover up the impropriety. A major takeaway from this series of papers is that an accumulation of small (and often unconscious) biased decisions in ambiguous situations may add up to major deviations from an objective standard, without an individual ever making a conscious choice to ignore ethical or professional standards; the authors argue that public policy that reduces the scope of conflicts of interest would be more effective than simply trying to punish individuals who act on them.

Moore, Tanlu, Bazerman (2010) ran multiple experiments investigating how both psychological factors and financial incentives impact auditor independence. In the first experiment, the authors examined how the behavior of 139 professional auditors was influenced by assigned 
role (hypothetically hired by either the firm to be valued or an outside investor). Participants that were told they were hired by the firm were significantly more likely to approve the firm's accounting than those told they were hired by an outside investor. ${ }^{54}$ Auditors working for the firm also valued the firm more highly than those working for outside investors, but the difference in valuations were not significant.

In a second experiment with 112 novices, Moore, Tanlu, Bazerman (2010) investigated how financial incentives interact with accountability relationships. Participants were assigned to one of four roles - buyer, buyer's agent, seller, or seller's agent - and asked to value and negotiate a price for a hypothetical firm. Agents were compensated with either a fixed fee (regardless of recommendation or outcome), based on the negotiated price, or presented with a monetary reward, at the principal's discretion, after the negotiation was complete (designed to represent "future business"). Buyers and sellers first made public announcements on the value of the firm. Unsurprisingly, sellers stated the firm was worth significantly more than the buyers. The agents then had the opportunity to endorse their principal's assessment or suggest changes. When compensated based on the negotiated price or with a fixed fee, the agents were roughly equally likely to endorse the principal's assessment or recommend changes to the stated valuation. When compensated with future business, however, $83 \%$ of agents recommend changes to the principal's valuation. Moreover, when recommending changes, $70 \%$ of agents paid based on the outcome and $67 \%$ of agents compensated with possible future business recommended a more extreme valuation (higher for the seller, lower for the buyer). The form of compensation, however, did not affect the agents' (public) assessments of the most the buyer should consider paying or the least the seller should consider accepting, nor their private valuations (disclosed only to the experimenter). Affiliation did affect the agents' perceived value of the firm (both public and private), providing further evidence that accountability relationships may impair auditor independence.

\section{Summary}

When facing a conflict of interest, professional auditors may sacrifice their independence in pursuit of financial rewards. Deis and Giroux (1992) present evidence that audit quality decreases as auditor tenure increases, possibly because auditors lower standards in an attempt to secure future business. ${ }^{55}$ Beeler and Hunton (2002) find that, in experiments, initially discounted prices may compromise auditor independence as they heighten the desire to

\footnotetext{
${ }^{54}$ The results are consistent with Buchman, Tetlock, and Reed (1996) who examined survey data and found auditors were significantly less likely to issue a qualified opinion if they were accountable to a client (consistent with the client's desires) than if they were accountable to a firm partner.

${ }^{55}$ It is important to keep in mind that the authors only examined audits performed for independent school districts in the state of Texas. As a result, the paper's results may not generalize to other types of evaluation, particularly ESOP valuations.
} 
maintain a long-term relationship. Other studies, however, have failed to find the same effect (Lee and Gu, 1998; DeAngelo, 1981).

There is mixed evidence regarding the impact that non-audit services have on auditor independence. Frankel, Johnson, and Nelson (2002), Kinney, Palmrose, and Scholz (2004), Ahadiat (2011), Markelevich and Rosner (2013), and Blay and Geiger (2013) find that non-audit services are associated with impaired auditor independence, but Antle et al. (2006), Ashbaugh, LaFond, and Mayhew (2003), Larcker and Richardson (2004), and Koh (2013) fail to find such evidence. Several studies suggest that one potential explanation for an ambiguous relationship between non-audit services and audit quality is non-auditor institutional oversight and the regulatory environment (Abdel-Meguid, Ahmad, and Duellman, 2011; Lim, Ding, and Charoenwong, 2013).

Professional auditors may also produce biased evaluations for purely psychological reasons. Bazerman, Morgan, and Loewenstein (1997), Bazerman, Loewenstein, and Moore (2002), and Moore et al. (2006) all suggest unconscious self-serving biases may impair auditor independence. Moore, Tanlu, and Bazerman (2010) find that an assigned role may influence evaluations and that this effect can be exacerbated by financial incentives.

7) Perspectives from the psychology literature on conflicts of interest

Traditional economic theories of decision-making tend to frame problems of conflicts of interest in terms of individuals choosing to act on their own incentives at the expense of professional obligations to their clients; the traditional economic lens suggests that the problems can be solved by making the punishment for ethical lapses sufficiently large to create an incentive not to pursue personal gain. The economically rational person is viewed as weighing the possibility of gain against the likelihood of punishment and acting accordingly. Psychology literature on conflicts of interest presents a different view of how decisions may become biased, with important implications for policy: penalties for biased action may not be effective if people cannot recognize the effects of bias on their own behavior, and mandatory disclosure of conflicts may not be an effective tool if individuals are unable or reluctant to discount conflicted advice appropriately.

At a fundamental cognitive level, Moore and Loewenstein (2004) argue that the instinct for selfinterest is an automatic process that can occur unconsciously, while determining one's obligations to others through moral or professional ethical codes is a more deliberative process that requires conscious effort. The primal nature of self-interest may win out even when a person is attempting to behave ethically, as they may not understand the extent to which selfinterest is biasing their judgment. Burks and Krupka (2011) find experimental evidence that 
misalignment between an advisor's personal norms and the ethical norms held by superiors and peers is associated with increased willingness to be dishonest.

Furthermore, once a biased opinion has been formed, giving a person a self-interested incentive to be unbiased may not overcome the original bias. Moore et al (2010) provide experimental evidence not only that individuals asked to provide public judgment in a partisan role give biased opinions, but also that when they are given explicit incentives to provide an objective private opinion, their judgments continue to be biased. This suggests that providing high-powered incentives for objectivity may not induce objective judgment, as individuals are unaware of the subtle effects of bias on their decision-making process.

Potential conflicts of interest are also a concern in the medical field: doctors and dentists are often compensated directly or indirectly for recommending particular treatments, in ways that may conflict with the interest of patients; the position of trust that medical professionals attain may exacerbate the problems of these conflicts. Schwartz, Luce, and Ariely (2011) use health care claims data to show that dental patients in long-standing relationships with their dentists are likely to choose more expensive (but not necessarily clinically superior) procedures; in experiments, they go on to show that patients are reluctant to seek second opinions for fear of damaging their dentist-patient relationship, and that clinically-irrelevant social behavior (a dentist granting or refusing to grant a personal favor to the patient) affects propensity to seek second opinions. Using survey data, Schwartz, Gino, and Ariely (2011) show that patients recognize conflicts of interest for other people's doctors but focus less on their own doctors; that patients are not concerned by 'indirect' conflicts of interest (e.g., doctors recommending a drug on which they are doing research); and that trust developed over time reduces the willingness of patients to discount potentially conflicted advice.

Menkhoff et al. (2013) suggest another possible cause of poor advice: overconfidence. Through an online experiment conducted in Germany, the authors found evidence that investment advisors are more overconfident than retail or institutional investors, which may cloud the advice they provide. Sah et al. (2013) find evidence that when feedback on the quality of advice is costly to retrieve or unavailable, highly confident advisors are perceived to be more credible and are more persuasive, regardless of accuracy.

\section{Summary}

The psychology papers presented here argue that bias in advice-giving can be unintentional and unconscious. One implication is that in the presence of conflicts of interest, even advisors who try to give unbiased advice may fail to do so. Policies designed to decrease biased advice should 
take into account that the bias may not be the result of deliberate choice, and therefore, penalties and sanctions for biased advice may have limited efficacy.

\section{8) Summary}

In an ideal setting with unrestricted panel data on investors' portfolios, transactions, access to advisors as well as data on advisors' compensation schemes and advice, we could make direct comparisons between advice rendered with and without the presence of conflicts of interests that fall under ERISA prohibited transactions. However, without such data, we can still gather evidence from existing literature.

In Section 1, we review the empirical evidence on financial advisors behavior and compensation schemes. The evidence suggests that compensation schemes have an influence on advisors' behavior and that investors who purchase through advisors earn lower returns than those who invest directly. However, it is important to bear in mind that these studies may have data limitations and in general cannot account for selection issues and the intangible benefits that investors may receive from financial advisors.

In our broader search of the effects of conflicts of interest, we also include evidence on conflicts of interest and bias in analyst reports. Even though analysts do not make personal recommendations to investors, they are similar to financial advisors in that they are tasked with providing advice on investment products. Similar to financial advisors, they may also face conflicts of interest insofar as their personal incentives may not be aligned with the goal of giving unbiased recommendations to the public. In Section 2, we present empirical evidence that suggests analysts (particularly sell-side analysts) were excessively optimistic prior to regulation in the early 2000s seeking to curb conflicts of interest. The literature, however, has produced mixed results on whether analyst biases have negatively affected investors, in general. Studies that have attempted to compare the impacts of analyst bias on individual and institutional investors have generally found that individual investors were more acutely impacted.

The literature on agency problems in mutual fund management also yields evidence that may be analogous to conflicts of interest in financial advice. In Section 3, our review of empirical work finds numerous agency problems in mutual fund management. Actively managed funds are frequently found to underperform comparable passively managed funds and mutual fund holders are often exposed to sizeable trading costs and brokerage commissions. Given that many Americans are unaware of the explicit fees that they pay for financial services, it is doubtful that many investors are fully aware of these costs, which tend to lack transparency. 
Given the survey and experimental evidence reviewed in Section 4, it is clear that investors desire and value the services that financial advisors provide. In Section 5, we discuss evidence on the efficacy of regulation and disclosure in mitigating conflicts of interest. The evidence presented on the effects of regulations on analysts shows that regulation can reduce bias. Disclosure, however, is unlikely to be an effective strategy if employed in isolation.

In Section 6 we review studies examining bias in professional auditor evaluations. There is evidence that auditors are influenced by conflicts of interest and that these influences may be subconscious.

Our review in Section 7 of psychological effects suggests it is important to keep in mind that regulation that reduces or eliminates conflicts of interest would be more effective than regulation that penalizes biased advice because biased advice may be unintentional and unconscious rather than the result of deliberate choice. 


\section{Bibliography}

"A Rash of Rules," Economist, Vol. 371, No. 8381, June 24, 2004, pp. 75-76.

“Advice from Whom?" Pensions \& Investments, Vol. 29, No. 14, 2001, pp. 10-10.

"Analysis Finds Fees Disclosed by Funds Understate 'True Costs'," Managing 401(k) Plans, Vol. 4, April 1, 2004, pp. 1-14.

"Avoiding Trouble with Stockbrokers," Consumers' Research Magazine, Vol. 78, No. 5, May 1995, pp. 19-19.

“Commissions Win the Day over Fees," American Banker, Vol. 176, No. 94, June 20, 2011, pp. 88.

"Cost of Conflicts," Pensions \& Investments, Vol. 35, 2007, pp. 10-10.

"FSA Seeks Revamp of Soft Commission, Bundled Arrangements," Securities Industry News, Vol. 15, No. 17, April 28, 2003, pp. 3.

"Going for Brokers," Economist, Vol. 371, No. 8373, April 29, 2004, pp. 77-78.

"Hard to Stop," Economist, Vol. 359, No. 8220, 2001, pp. 67-68.

"How to Pay Brokers," Economist, Vol. 360, No. 8233, 2001, pp. 59-60.

"Let the Buyers Be Aware," Business Insurance, Vol. 32, 1998, pp. 8-8.

"Marching Toward Fees," Journal of Financial Planning, Vol. 16, No. 8, August 2003, pp. 18.

"Plan Sponsors Poised to Crack Down on 401(k) Plan Fees," Managing 401(k) Plans, Vol. 10, October 1, 2006, pp. 2-4.

"Professionals Prefer Impartial Fee-based Advice," Money Marketing, September 11, 2003, pp.13.

"SEC Examines Pay-to-play," Pensions \& Investments, Vol. 32, January 26, 2004, pp. 10-10.

"Seller Beware," Economist, Vol. 370, No. 8358, 2004, pp. 65.

"Warning Signs Your 401(k) Adviser May Not Be Independent," Managing 401(k) Plans, Vol. 5, May 1, 2008, pp. 1-7.

Abdel-Meguid, Ahmed M., Anwer S. Ahmed, and Scott Duellman. "Auditor independence, corporate governance and aggressive financial reporting: an empirical analysis." Journal of Management \& Governance, Vol. 17, No. 2, 2013, pp. 283-307.

Adams, John C., Sattar A. Mansi, and Takeshi Nishikawa. "Are mutual fund fees excessive?." Journal of Banking \& Finance, Vol. 36, No. 8, 2012, pp. 2245-2259.

Agrawal, Anup, and Mark A. Chen. "Analyst conflicts and research quality." The Quarterly Journal of Finance, Vol. 2, No. 2, 2012, pp. 1-40.

Agrawal, Anup, and Mark A. Chen, "Do Analyst Conflicts Matter? Evidence from Stock Recommendations," The Journal of Law \& Economics, Vol. 51, No. 3, 2008, pp. 503-537.

Ahadiat, Nasrollah. "Association between audit opinion and provision of non-audit services." International Journal of Accounting and Information Management, Vol. 19 No. 2, 2011, pp. 182-193.

Angelova, Vera, and Tobias Regner. "Do voluntary payments to advisors improve the quality of financial advice? An experimental deception game." Journal of Economic Behavior \& Organization, 2013.

Antle, Rick, Elizabeth A. Gordon, Ganapathi Narayanamoorthy, and Ling Zhou, "The Joint Determination of Audit Fees, Non-Audit Fees, and Abnormal Accruals," Review of Quantitative Finance and Accounting, Vol. 3, 2006, pp. 235-266. 
Ashbaugh Skaife, Hollis, Ryan LaFond, and Brian W. Mayhew, "Do non-audit services compromise auditor independence? Further evidence," Accounting Review, Vol. 78, 2003, pp. 611-639.

Asthana, Sharad C., and Jeff P. Boone. "Abnormal audit fee and audit quality." AUDITING: A Journal of Practice \& Theory, Vol. 31, No. 3, 2012, pp. 1-22.

Australian Securities \& Investment Commission (ASIC), Shadow Shopping Survey on Superannuation Advice, Report 69, April 2006. As of May 30, 2012: http://www.asic.gov.au/asic/pdflib.nsf/LookupByFileName/shadow_shop_report_2006. pdf/\$file/shadow_shop_report_2006.pdf

Bajari, Patrick, and John Krainer, An Empirical Model of Stock Analysts' Recommendations: Market Fundamentals, Conflicts of Interest, and Peer Effects, NBER Working Paper No. 10665, August 2004.

Baker, William and Gregory Dumont, "Equity Analyst Recommendations: A Case for Affirmative Disclosure?” Journal of Consumer Affairs, Vol. 48, No. 1, 2014, 96-123.

Barber, Brad M., Reuven Lehavy, and Brett Trueman, "Comparing the Stock Recommendation Performance of Investment Banks and Independent Research Firms," Journal of Financial Economics, Vol. 85, No. 2, 2007, pp. 490-517.

Barniv, Ran, Ole-Kristian Hope, Mark J. Myring, and Wayne B. Thomas, "Do Analysts Practice What They Preach and Should Investors Listen? Effects of Recent Regulations," Accounting Review, Vol. 84, No. 4, 2009, pp. 1015-1039.

Bazerman, Max H., George Loewenstein, and Don A. Moore, "Why Good Accountants Do Bad Audits," Harvard Business Review, Vol. 80, No. 11, 2002, pp. 96-103.

Bazerman, Max H., Kimberly P. Morgan, and George F. Loewenstein, "The Impossibility of Auditor Independence," Sloan Management Review, Vol. 38, No. 4, 1997, pp. 89-94.

Beeler, Jesse D., and James E. Hunton, "Contingent Economic Rents: Insidious Threats to Audit Independence," Advances in Accounting Behavioral Research, Vol. 5, 2002, pp. 3-17.

Bell, Brian, Christopher J. Denney, Brian Quinn, Lillian Shields, and Holden B. Weisman, "Assessing Investment Advice Provided to Participants in Defined Contribution Plans," Madison, Wis.: University of Wisconsin-Madison, Working paper, 2010.

Bergstresser, Daniel, John M. R. Chalmers, and Peter Tufano, "Assessing the Costs and Benefits of Brokers in the Mutual Fund Industry," Review of Financial Studies, Vol. 22, No. 10, 2009, pp. 4129-4156.

Berk, Jonathan B., and Richard C. Green, "Mutual Fund Flows and Performance in Rational Markets," Journal of Political Economy, Vol. 112, No. 6, 2004, pp. 1269-1295.

Berzins, Janis, Crocker H. Liu, and Charles Trzcinka. "Asset management and investment banking." Journal of Financial Economics, Vol. 110, No. 1, 2013, pp. 215-231.

Bessler, Wolfgang, and Matthias Stanzel, "Conflicts of Interest and Research Quality of Affiliated Analysts in the German Universal Banking System: Evidence from IPO Underwriting," European Financial Management, Vol. 15, No. 4, 2009, pp. 757-786.

Beyer, Max, David de Meza, and Diane Reyniers. "Do financial advisor commissions distort client choice?." Economics Letters, Vol. 119, No. 2, 2013, pp. 117-119.

Bhattacharya, Utpal, Andreas Hackethal, Simon Kaesler, Benjamin Loos, and Steffen Meyer. "Is unbiased financial advice to retail investors sufficient? Answers from a large field study." Review of Financial Studies, Vol. 25, No. 4, 2012, pp. 975-1032. 
Blay, Allen D., and Marshall A. Geiger, "Auditor Fees and Auditor Independence: Evidence from Going Concern Reporting Decisions," Contemporary Accounting Research, Vol. 30, No. 2, 2011, pp. 579-606.

Bluethgen, Ralph, Steffen Meyer, and Andreas Hackethal, "High Quality Financial Advice Wanted!" Journal of Economic Literature, February 2008.

Bolton, Patrick, Xavier Freixas, and Joel Shapiro, "Conflicts of Interest, Information Provision, and Competition in the Financial Services Industry," Journal of Financial Economics, Vol. 85 , No. 2, 2007, pp. 297-330.

Boudry, Walter I., Jarl G. Kallberg, and Crocker H. Liu. "Analyst Behavior and Underwriter Choice." The Journal of Real Estate Finance and Economics, Vol. 43, No. 1-2, 2011, pp. 538.

Bradley, Daniel, Jonathan Clarke, and John Cooney Jr. "The impact of reputation on analysts' conflicts of interest: Hot versus cold markets." Journal of Banking \& Finance, Vol. 36, No. 8, 2012, pp. 2190-2202.

Buchman, Thomas A., Philip E. Tetlock, and Ronald Reed, "Accountability and Auditors' Judgment about Contingent Events," Journal of Business Finance and Accounting, Vol. 23, No. April 1996, 1996, pp. 379-398.

Bullard, Mercer, Geoffrey C. Friesen, and Travis Sapp, "Investor Timing and Fund Distribution Channels," SSRN Working Paper, June 1, 2008. As of June 1, 2012: http://ssrn.com/abstract=1070545 or http://dx.doi.org/10.2139/ssrn.1070545

Burks, Stephen V., and Erin L. Krupka. "A Multimethod Approach to Identifying Norms and Normative Expectations within a Corporate Hierarchy: Evidence from the Financial Services Industry." Management Science, Vol. 58, No. 1, 2012, pp. 203-217.

Byrne, Alistair, lain Clacher, David Hillier, and Allan Hodgson, "Fair Value Accounting and Managerial Discretion," Leeds University Business School Working Paper, January 2008. As of May 30, 2012: http://ssrn.com/abstract=1101691 or http://dx.doi.org/10.2139/ssrn.1101691

Cain, Daylian M., George Loewenstein, and Don A. Moore, "The Dirt on Coming Clean: Perverse Effects of Disclosing Conflicts of Interest," Journal of Legal Studies, Vol. 34, No. 1, 2005, pp. 1-25.

---------, "When Sunlight Fails to Disinfect: Understanding the Perverse Effects of Disclosing Conflicts of Interest," Journal of Consumer Research, Vol. 37, No. 5, 2011, pp. 836-857.

Calcagno, Riccardo, and Chiara Monticone, "Financial Literacy and the Demand for Financial Advice," Journal of Banking and Finance, forthcoming, 2014

Cao, Jian, and Mark Kohlbeck. "Analyst Quality, Optimistic Bias, and Reactions to Major News." Journal of Accounting, Auditing \& Finance Vol. 26, No. 3, 2011, pp. 502-526.

Casey, Ryan J. "Do independent research analysts issue more or less informative recommendation revisions?." Advances in Accounting, Vol. 29, No. 1, 2013, pp. 36-49.

Cashman, George D. "Convenience in the mutual fund industry." Journal of Corporate Finance, Vol. 18, No. 5, 2012, pp. 1326-1336.

Chalmers, John and Jonathan Reuter, "What is the Impact of Financial Advisors on Retirement Portfolio Choices and Outcomes?," Working Paper, 2014

Chan, Louis K. C., Jason Karceski, Joseph Lakonishok, "Analysts' Conflicts of Interest and Biases in Earnings Forecasts," Journal of Financial \& Quantitative Analysis, Vol. 42, No. 4, 2007, 
pp. 893-913.

Chang, Millicent, and Juliana Ng, "The Influence of Analyst and Management Forecasts on Investor Decision Making: An Experimental Approach," Australian Journal of Management, Vol. 33, No. 1, June 2008, pp. 47-67.

Charles River Associates, "Polarisation: Research into the Effect of Commission Based Remuneration on Advice," London: Charles River Associates Ltd., January 2002. As of November 1, 2011: http://www.fsa.gov.uk/pubs/other/pol res1.pdf

Chater, Nick, Steffen Huck, and Roman Inderest. "Consumer Decision-Making in Retail Investment Services: A Behavioural Economics Perspective." November 2010.

Chen, Carl R., and Ying Huang. "Mutual fund governance and performance: a quantile regression analysis of Morningstar's Stewardship Grade." Corporate governance: An International Review, Vol. 19, No. 4, 2011, pp. 311-333.

Chen, Joseph, Jeffrey D. Kubik, and Harrison G. Hong, "Outsourcing mutual fund management: firm boundaries, incentives, and performance." The Journal of Finance, Vol. 68, No. 2, 2013, 523-558.

Chen, Xuanjuan, Tong Yao, and Tong Yu, "Prudent Man or Agency Problem? On The Performance of Insurance Mutual Funds," Journal of Financial Intermediation, Vol. 16, No. 2, April 2007, pp. 175-203.

Cheng, Yingmei, Mark H. Liu, and Jun Qian, "Buy-side Analysts, Sell-Side Analysts, and Investment Decisions of Money Managers," Journal of Financial and Quantitative Analysis, Vol. 41, No. 1, March 2006, pp. 51-83.

Chih-Ying, Chen, and P. F. Chen, "NASD Rule 2711 and Changes in Analysts' Independence in Making Stock Recommendations," Accounting Review, Vol. 84, No. 4, July 2009, pp. 1041-1071.

Christoffersen, Susan Kerr, Richard B. Evans, and David K. Musto, "What do consumers' fund flows maximize? Evidence from their brokers' incentives." The Journal of Finance, Vol. 68 , No. 1, 2013, pp. 201-235.

Church, Bryan K., and Xi (Jason) Kuang, "Conflicts of Interest, Disclosure, and (Costly) Sanctions: Experimental Evidence," Journal of Legal Studies, Vol. 38, No. 2, 2009, pp. 505-532.

Clarke, Jonathan, Stephen P. Ferris, Jinsoo Lee, and Narayanan Jayaraman, "Are Analyst Recommendations Biased? Evidence from Corporate Bankruptcies," Journal of Financial \& Quantitative Analysis, Vol. 41, No. 1, 2006, pp. 169-196.

Clements, Curtis E., John D. Neill, and O. Scott Stovall. "Inherent Conflicts Of Interest In The Accounting Profession." Journal of Applied Business Research (JABR), Vol. 28, No. 2, 2012, pp. 269-276.

Coleman, Anthony D. F., Neil Esho, and Michelle Wong, "The Impact of Agency Costs on the Investment Performance of Australian Pension Funds," Journal of Pension Economics and Finance, Vol. 5, No. 3, 2006, pp. 299-324.

Cumming, Douglas, Sofia Johan, and Dan Li, "Exchange Trading Rules and Stock Market Liquidity," Journal of Financial Economics, Vol. 99, No. 3, March 2011, pp. 651-671.

Danilov, Anastasia, Torsten Biemann, Thorn Kring, and Dirk Sliwka. "The dark side of team incentives: Experimental evidence on advice quality from financial service professionals." Journal of Economic Behavior \& Organization, 2013. 
De Franco, Gus, Hai Lu, and Florin P. Vasvari, "Wealth Transfer Effects of Analysts' Misleading Behavior," Journal of Accounting Research, Vol. 45, No. 1, March 2007, pp. 71-110.

DeAngelo, Linda Elizabeth, "Auditor Independence, Low Balling, and Disclosure Regulation," Journal of Accounting and Economics, Vol. 3, No. 2, 1981, pp. 113-127.

DeCarlo, Thomas E., Russell Laczniak, and Thomas Leigh "Selling financial services: The effect of consumer product knowledge and salesperson commission on consumer suspicion and intentions" Journal of the Academy of Marketing Science, Vol. 41, No. 4, 2013, pp. 418435.

Deis, Donald R., and Gary A. Giroux, (1992). "Determinants of Audit Quality in the Public Sector," Accounting Review, Vol. 67, No. 3, pp. 462-479.

Del Guercio, Diane and Jonathan Reuter, "Mutual Fund Performance and the Incentive to Generate Alpha," Journal of Finance Vol. 69, No. 4, August 2014, pp. 1673-1704.

Del Guercio, Diane, Jonathan Reuter, and Paula A. Tkac, Broker Incentives and Mutual Fund Market Segmentation, NBER Working Paper No. w16312, August 2010.

Deloitte, "Defined Contribution / 401 (k) Fee Study: Inside the Structure of Defined Contribution / 401(k) Plan Fees: A Study Assessing the Mechanics of What Drives the 'All-In' Fee," Spring 2009 - updated June 2009. As of May 30 2012: http://www.ici.org/pdf/rpt_09_dc_401k_fee_study.pdf

Demski, Joel S. (2003). "Corporate Conflicts of Interest," Journal of Economic Perspectives, Vol. 17, No. 2, 2003, pp. 51-72.

Department for Work \& Pensions, "Landscape and Charges Survey 2013: Charges and Quality in Defined Contribution Pension Schemes," Research Report No. 859, 2014

Dichev, Ilia D., and Gwen Yu. "Higher risk, lower returns: What hedge fund investors really earn." Journal of Financial Economics, Vol. 100, No. 2, 2011, pp. 248-263.

Dominitz, Jeff, Angela Hung, and Joanne K. Yoong, How Do Mutual Fund Fees Affect Investor Choices? Santa Monica, Calif.: RAND Corporation, WR-653, 2009. As of May 30, 2012: http://www.rand.org/pubs/working_papers/WR653/

Dopuch, Nicholas, Ronald R. King, and Rachel Schwartz, "Independence in Appearance and in Fact: An Experimental Investigation," Contemporary Accounting Research, Vol. 20, No. 1, 2003, pp. 79-114.

Doty, Robert W., "Recognize Financial Advisers' Duty, Don't Destroy It," Bond Buyer, Vol. 372, No. 33293, 2010, pp. 6-6.

Dubois, Michel, Laurent Fresard and Pascal Dumontier, "Regulating Conflicts of Interest: The Effect of Sanctions and Enforcement," Review of Finance, Vol. 18, No. 2, 2014, pp. 489526.

Duska, Ronald, "The Ethics of Reward Systems in the Financial Services Industry," Business \& Society Review, Vol. 104, No. 1, Spring 1999, pp. 34-41.

Dvorak, Tomas, "Do 401k Advisors Take Their Own Advice?" Journal of Pension Economics and Finance, 2014, pp. 1-21

Edelen, Roger M., Richard B. Evans, and Gregory B. Kadlec. "Disclosure and agency conflict: Evidence from mutual fund commission bundling." Journal of Financial Economics, Vol. 103, No. 2, 2012, pp. 308-326.

Edelen, Roger M., Richard Evans, and Gregory B. Kadlec, Scale Effects in Mutual Fund Performance: The Role of Trading Costs, Working paper, March 17, 2007. As of May 30, 
2012:

http://dx.doi.org/10.2139/ssrn.951367

Elton, Edwin J., Martin J. Gruber, Sanjiv Das, and Matthew Hlavka, "Efficiency with Costly Information - a Reinterpretation of Evidence from Managed Portfolios," Review of Financial Studies, Vol. 6, No. 1, 1993, pp. 1-22.

Ertimur, Yonca, Jayanthi Sunder, and Shyam V. Sunder, "Measure for Measure: The Relation between Forecast Accuracy and Recommendation Profitability of Analysts," Journal of Accounting Research, Vol. 45, No. 3, 2007, pp. 567-606.

Ertimur, Yonca, Volkan Muslu, and Frank Zhang. "Why are recommendations optimistic? Evidence from analysts' coverage initiations." Review of Accounting Studies, Vol. 16, No. 4, 2011, pp. 679-718.

Evans, Richard, and Rudiger Fahlenbrach, "Do Funds Need Governance? Evidence from Variable Annuity-Mutual Fund Twins," Columbus, Ohio: Ohio State University, Charles A. Dice Center for Research in Financial Economics, Working Paper Series, December 2007.

Fang, Lily, and Ayako Yasuda, "The Effectiveness of Reputation as a Disciplinary Mechanism in Sell-Side Research," Review of Financial Studies, Vol. 22, No. 9, 2009, pp. 3735-3777.

Fatemi, Darius J. "An experimental investigation of the influence of audit fee structure and auditor selection rights on auditor independence and client investment decisions." Auditing: A Journal of Practice \& Theory, Vol. 31, No. 3, 2012, pp. 75-94.

Financial Conduct Authority (FCA), "Supervising Retail Investment Advice: How Firms Are Implementing the RDR," Thematic Review, 2013a, TR13/5

---------, "Supervising Retail Investment Advice: Inducements and Conflicts of Interest," Guidance Consultation, 2013b

---------, "Supervising Retail Investment Advice: Delivering Independent Advice," Thematic Review, 2014, TR14/5

Ferris, Stephen P., and Xuemin Yan, "Agency Conflicts in Delegated Portfolio Management: Evidence from Namesake Mutual Funds," Journal of Financial Research, Vol. 30, No. 4, 2007, pp. 473-494.

Financial Crisis Inquiry Commission, "The Financial Crisis Inquiry Report," Washington, D.C.: U.S. Government Printing Office, January 2011. As of January 25, 2012: http://fcic-static.law.stanford.edu/cdn_media/fcic-reports/fcic_final_report_full.pdf

Financial Services Authority (FSA), "11.8 Billion Compensation for Pensions and FSAVC Reviews," June 27, 2002. As of November 1, 2011: http://www.fsa.gov.uk/Pages/Library/Communication/PR/2002/070.shtml , "Bundled Brokerage and Soft Commission Arrangements: Feedback on CP05/5 and Final Rules," July 2005. As of May 30, 2012: http://www.fsa.gov.uk/pubs/policy/ps05_09.pdf -, "Delivering the Retail Distribution Review: Corporate pensions - feedback to CP09/31 and final rules," June 2010. As of May 20, 2012: http://www.fsa.gov.uk/pubs/policy/ps10_10.pdf

Firth, Michael, Chen Lin, Ping Liu, and Yuhai Xuan, "The Client is King: Do Mutual Fund Relationships Bias Analyst Recommendations?." Journal of Accounting Research, Vol. 51, No. 1, 2013 pp. 165-200.

Frankel, Richard M., Marilyn Johnson, and Karen K. Nelson, "The relation between auditors' 
fees for non-audit services and earnings management," Accounting Review, Vol. 77, Supplement: Quality of Earnings Conference, 2002, pp. 71-105.

Frankel, Tamar. "The Failure of Investor Protection by Disclosure." University of Cincinnati Law Review, Vol. 81, No. 2, 2012, pp. 421-442.

Friesen, Geoffrey C., and Travis Sapp, "Mutual Fund Flows and Investor Returns: An Empirical Examination of Fund Investor Timing Ability," Journal of Banking \& Finance, Vol. 31, No. 9, 2007, pp. 2796-2816.

Georgarakos, Dimitris, and Roman Inderst, "Financial Advice and Stock Market Participation," European Central Bank, Working Paper No. 1296, March 13, 2012.

Gil-Bazo, Javier, and Pablo Ruiz-Verdú, "The Relation between Price and Performance in the Mutual Fund Industry," The Journal of Finance, Vol. 64, No. 5, 2009, pp. 2153-2183.

---------, "When Cheaper is Better: Fee Determination in the Market for Equity Mutual Funds," Journal of Economic Behavior \& Organization, Vol. 67, No. 3-4, 2008, pp. 871-885.

Gino, Francesca, "Do We Listen to Advice Just Because We Paid For It? The Impact of Advice Cost on Its Use," Organizational Behavior \& Human Decision Processes, Vol. 107, No. 2, 2008, pp. 234-245.

Gino, Francesca, Alison W. Brooks, and Maurice E. Schweitzer, "Anxiety, Advice, and the Ability to Discern: Feeling Anxious Motivates Individuals to Seek and Use Advice," Journal of Personality and Social Psychology, Vol. 102, No. 3, March 2012, pp. 497-512.

Gorter, Janko. "Commission Bans and the Source and Quality of Financial Advice." Netherlands Central Bank, Research Department, DNB Working Papers, 2012.

Grant, James, "Eliot Spitzer, White Knight," Forbes, Vol. 169, No. 11, 2002, pp. 190.

Groysberg, Boris, Paul Healy, George Serafeim, and Devin Shanthikumar, "The stock selection and performance of buy-side analysts." Management Science, Vol. 59, No. 5, 2013 pp. 1062-1075.

Gu, Zhaoyang, and Jian Xue, "The Superiority and Disciplining Role of Independent Analysts," Journal of Accounting \& Economics, Vol. 45, No. 2/3, August 2008, pp. 289-316.

$\mathrm{Gu}$, Zhaoyang, Zengquan Li, and Yong George Yang. "Monitors or Predators: The Influence of Institutional Investors on Sell-Side Analysts." The Accounting Review, Vol. 88, No. 1, 2013, pp. 137-169.

Guiso, Luigi, Paola Sapienza, and Luigi Zingales, "Trusting the Stock Market," The Journal of Finance, Vol. 63, No. 6, 2008, pp. 2557-2600.

Hackethal, Andreas, Michael Haliassos, and Tullio Jappelli. "Financial advisors: A case of babysitters?" Journal of Banking \& Finance, Vol. 36, No. 2, 2012, pp. 509-524.

Hackethal, Andreas, Roman Inderst, and Steffen Meyer, "Trading on Advice," Discussion Paper No. 8091, 2010.

Hales, Jeffrey, "Directional Preferences, Information Processing, and Investors' Forecasts of Earnings," Journal of Accounting Research, Vol. 45, No. 3, 2007, pp. 607-628.

Halifax, "A Decade of ISAs," Press Release, February 17, 2010. As of May 30, 2012: http://www.Iloydsbankinggroup.com/media/pdfs/halifax/2010/ISAtrendsvFinal.pdf

Hao, Grace, and Xuemin Sterling Yan. "The Performance of Investment Bank-Affiliated Mutual Funds: Conflicts of Interest or Informational Advantage?." Journal of Financial and Quantitative Analysis (JFQA), Vol. 47, No. 3, 2012, pp. 537-565.

Haslem, Jonh A., "Assessing Mutual Fund Expenses and Transaction Costs," Journal of Investing, 
Vol. 15, No. 3, 2006, pp. 52-56.

Hill, Patrice, "Investment fraud costs brokerages; 10 firms to pay $\$ 1.4$ billion in fines, hold billions for suits," The Washington Times, April 29, 2003, pp. 1.

Hong, Harrison, and J. D. Kubik (2003), "Analyzing the Analysts: Career Concerns and Biased

Earnings Forecasts," Journal of Finance, Vol. 58, No. 1, 2003, pp. 313-351.

Hong, Harrison, and Marcin Kacperczyk, "Competition and Bias," Quarterly Journal of Economics, Vol. 125, No. 4, 2010, pp. 1683-1725.

Horan, Stephen M., and D. Bruce Johnsen, "Can Third-party Payments Benefit the Principal? The Case of Soft Dollar Brokerage," International Review of Law \& Economics, Vol. 28, No. 1, 2008, pp. 56-77.

Hortacsu, Ali, and Chad Syverson, "Product Differentiation, Search Costs, and Competition in the Mutual Fund Industry," Quarterly Journal of Economics, Vol. 119, No. 2, 2004, pp. 403-456.

Howat, John, and Linda Reid, "Compensation Practices for Retail Sale of Mutual Funds: The Need for Transparency and Disclosure," Fordham Journal of Corporate \& Financial Law, Vol. 12, No. 4, 2007, pp. 685-716.

Hung, Angela A., and Joanne Yoong, Asking for Help: Survey and Experimental Evidence on Financial Advice and Behavior Change, Santa Monica, Calif.: RAND Corporation, WR-7141, 2010. As of June 1, 2012: http://www.rand.org/pubs/working_papers/WR714-1/

Hung, Angela A., Noreen Clancy, Jeff Dominitz, Eric Talley, Claude Berrebi, and Farrukh Suvankulov, Investor and Industry Perspectives on Investment Advisers and BrokerDealers, Santa Monica, Calif.: RAND Corporation, TR-556-SEC, 2008. As of June 1, 2012: http://www.rand.org/pubs/technical_reports/TR556/

Inderst, Roman, and Marco Ottaviani. "Competition through Commissions and Kickbacks." The American Economic Review, Vol. 102, No. 2, 2012, pp. 780-809.

Inderst, Roman, and Marco Ottaviani. "Financial advice." Journal of Economic Literature, Vol. 50, No. 2, 2012, pp. 494-512.

Inderst, Roman, and Marco Ottaviani, "How (Not) to Pay for Advice: A Framework For Consumer Protection," Working Paper, 2009a.

-, "Misselling through Agents," American Economic Review, Vol. 99, No. 3, 2009b, pp. 883-908.

Investment Company Institute, "Appendix: Additional Data on IRA Ownership in 2011," Research Prospective, Vol. 17, No. 8A, 2011b. As of May 30, 2012: http://www.ici.org/pdf/per17-08_appendix.pdf

--------, "Characteristic of Mutual Fund Investors, 2011," Research Prospective, Vol. 17, No. 6, 2011c. As of May 30, 2012: http://www.ici.org/pdf/per17-06.pdf , "Profile of Mutual Fund Shareholders," Research Series, October 2004. -, "The IRA Investor Profile, Traditional IRA Investors' Asset Allocation, 2007 and 2008," 2011a. As of May 30, 2012: http://www.ici.org/pdf/rpt_11_ira_asset.pdf -, "The Role of IRAs in U.S. Households' Saving for Retirement, 2011," Research Prospective, Vol., 17, No. 8, 2011d. As of May 30, 2012: 
http://ici.org/pdf/per17-08.pdf

, "The U.S. Retirement Market, 2009," Research Fundamentals, Vol. 19, No. 3, May

2010. As of May 30, 2012:

http://www.ici.org/pdf/fm-v19n3.pdf

--------, "Why Do Mutual Fund Investors Use Professional Financial Advisers?" Research

Fundamentals, Vol. 16, No. 1, April 2007. As of May 30, 2012:

http://www.ici.org/pdf/fm-v16n1.pdf

Johnston, Rick. "Does Analyst Stock Ownership Affect Reporting Behavior?." Review of Pacific Basin Financial Markets and Policies, Vol. 16, No. 2, 2013, pp. 1-39.

Jones, Ceri, "Out of Commission," Employee Benefits, September 2010, pp. 28-29.

Kadan, Ohad, Leonardo Madureira, Rong Wang, Tzachi Zach, and Chenchuramaiah T. Bathala, "Conflicts of Interest and Stock Recommendations: The Effects of the Global Settlement and Related Regulations," Review of Financial Studies, Vol. 22, No. 10, 2009, pp. 41894217.

Karamanou, Irene. "On the determinants of optimism in financial analyst earnings forecasts: The effect of the market's ability to adjust for the bias." Abacus, Vol. 47, No. 1, 2011, pp. 1-26.

Karceski, Jason, Miles Livingston, and Edward S. O’Neal. "Mutual fund brokerage commissions." Journal of Financial Research, Vol. 19, 2004, pp. 273-292.

$\mathrm{Ke}$, Bin, and Yong Yu, "The Effect of Issuing Biased Earnings Forecasts on Analysts' Access to Management and Survival," Journal of Accounting Research, Vol. 44, No. 5, 2006, pp. 965-999.

Kelly, Khim, Bernardine Low, Hun-Tong Tan, and Seet-Koh Tan. "Investors' Reliance on Analysts' Stock Recommendations and Mitigating Mechanisms for Potential Overreliance." Contemporary Accounting Research, Vol. 29, No. 3, 2012, pp. 991-1012.

Kinney, William, Zoe-Vonna Palmrose, and Susan Scholz, "Auditor independence, non-audit services, and restatements: Was the U. S. government right?" Journal of Accounting Research, Vol. 42, No. 3, 2004, pp. 561-588.

Koh, Kevin, Shiva Rajgopal, and Suraj Srinivasan. "Non-audit services and financial reporting quality: evidence from 1978 to 1980." Review of Accounting Studies, Vol. 18, No. 1, 2013, pp. 1-33.

Kolasinski, Adam C., and S. P. Kothari, "Investment Banking and Analyst Objectivity: Evidence from Analysts Affiliated with Mergers and Acquisitions Advisors," Journal of Financial \& Quantitative Analysis, Vol. 43, No. 4, 2008, pp. 817-842.

Krausz, Miriam, and Jacob Paroush, "Financial Advising in the Presence of Conflict of Interests." Journal of Economics \& Business, Vol. 54. No. 1, 2002, pp. 55-71.

Lach, Patrick A., Michael J. Highfield, and Stephen D. Treanor, "The Quiet Period Has Something to Say," Applied Financial Economics, Vol. 22, No. 1, 2012, pp. 71-86.

Larcker, David, and Scott A. Richardson, "Fees Paid to Audit Firms, Accrual Choices, and Corporate Governance," Journal of Accounting Research, Vol. 42, No. 3, 2004, pp. 625658.

Lee, Cheolwoo. "Analyst firm parent-subsidiary relationship and conflict of interest: evidence from IPO recommendations." Accounting \& Finance, Vol. 53, No. 3, 2012, pp. 763-789. 
Lee, Chi-Wen Jevons, and Zhaoyang Gu, "Low Balling, Legal Liability and Auditor Independence," Accounting Review, Vol. 73, No. 4, October 1998, pp. 533-555.

Liao, Yihsing, Wuchun Chi, and Yunshan Chen. "Auditor Economic Dependence and Accounting Conservatism: Evidence from a Low Litigation Risk Setting." International Journal of Auditing, Vol. 17, No. 2, 2013, pp. 117-137.

Li, C. Wei, and Ashish Tiwari, "Incentive Contracts in Delegated Portfolio Management," Review of Financial Studies, Vol. 22, No. 11, 2009, pp. 4681-4714.

Libby, Robert, James E. Hunton, Hun-Tong Tan, and Nicholas Seybert, "Relationship Incentives and the Optimistic/Pessimistic Pattern in Analysts' Forecasts," Journal of Accounting Research, Vol. 46, No. 1, 2008, pp. 173-198.

Lim, Chee Yeow, David K. Ding, and Charlie Charoenwong. "Non-audit fees, institutional monitoring, and audit quality." Review of Quantitative Finance and Accounting, Vol. 41, No. 2, 2013, pp. 343-384.

Livingston, Miles, and Edward S. O'Neal, "Mutual Fund Brokerage Commissions," Journal of Financial Research, Vol. 19, No. 2, 1996, pp. 273-292.

Ljungqvist, Alexander, Felicia Marston, Laura T. Starks, Kelsey D. Wei, and Hong Yan, "Conflicts of Interest in Sell-Side Research and the Moderating Role of Institutional Investors," Journal of Financial Economics, Vol. 85, No. 2, 2007, pp. 420-456.

Loewenstein, George, Daylian M. Cain, and Sunita Sah, "The Limits of Transparency: Pitfalls and Potential of Disclosing Conflicts of Interest," American Economic Review: Papers and Proceedings, Vol. 101, No. 3, 2011, pp. 423-428.

Lusardi, Annamaria, and Olivia S. Mitchell, "Baby Boomer Retirement Security: The Roles of Planning, Financial Literacy, and Housing Wealth," Journal of Monetary Economics, Vol. 54, No. 1, 2007a, pp. 205-224.

---------, "Financial Literacy and Retirement Planning: New Evidence from the RAND American Life Panel," MRRC Working Paper No. 2007-157, 2007b.

---------, “Financial Literacy and Planning: Implications for Retirement Wellbeing," NBER Working Paper No. 17078, May 2011.

---------, "Financial Literacy and Planning: Implications for Retirement Wellbeing," Philadelphia, Pa.: Wharton School, University of Pennsylvania, Pension Research Council Working Paper No. 1, January 2006.

Mahoney, Paul G., "Manager-Investor Conflicts in Mutual Funds," Journal of Economic Perspectives, Vol. 18, No. 2, 2004, pp. 161-182.

Malmendier, Ulrike, and Devin Shanthikumar, "Are Small Investors Naive about Incentives?" Journal of Financial Economics, Vol. 85, No. 2, 2007, pp. 457-489.

Markelevich, Ariel, and Rebecca L. Rosner. "Auditor fees and fraud firms." Contemporary Accounting Research, 2013.

Mehran, Hamid, and Rene M. Stulz, "The Economics of Conflicts of Interest in Financial Institutions," Journal of Financial Economics, Vol. 85, No. 2, 2007, pp. 267-296.

Menkhoff, Lukas, Maik Schmeling, and Ulrich Schmidt. "Overconfidence, experience, and professionalism: An experimental study." Journal of Economic Behavior \& Organization, Vol. 86, 2013, pp. 92-101.

Michaely, Roni, and Kent L. Womack, "Conflict of Interest and the Credibility of Underwriter Analyst Recommendations," Review of Financial Studies, Vol. 12, No. 4, 1999, pp. 653- 
686.

Mikhail, Mikhail B., Beverly R. Walther, and Richard H. Willis, "When Security Analysts Talk, Who Listens?" Accounting Review, Vol. 82, No. 5, 2007, pp. 1227-1253.

Mola, Simona, and Massimo Guidolin, "Affiliated Mutual Funds and Analyst Optimism," Journal of Financial Economics, Vol. 93, No. 1, 2009, pp. 108-137.

Moore, Don A., and George Loewenstein, "Self-Interest, Automaticity, and the Psychology of Conflict of Interest," Social Justice Research, Vol. 17, No. 2, 2004, pp. 189-202.

Moore, Don A., Lloyd Tanlu, and Max H. Bazerman, "Conflict of Interest and the Intrusion of Bias," Judgment and Decision Making, Vol. 5, No. 1, 2010, pp. 37-53.

Moore, Don A., Philip E. Tetlock, Lloyd Tanlu, and Max H. Bazerman, "Conflicts of Interest and the Case of Auditor Independence: Moral Seduction and Strategic Issue Cycling," Academy of Management Review, Vol. 31, No. 1, 2006, pp. 10-29.

Morey, Matthew R., "Should You Carry the Load? A Comprehensive Analysis of Load and NoLoad Mutual Fund Out-of-sample Performance," Journal of Banking \& Finance, Vol. 27, No. 7, 2003, pp. 1245-1271.

Mullainathan, Sendhil, Markus Noeth, and Antoinette Schoar, The Market for Financial Advice: An Audit Study, NBER Working Paper No. w17929, March 2012.

Nash, Jeff, "2 of 3 Participants Don't Read Info," Pensions \& Investments, Vol. 37, No. 21, 2009, pp. 2-42.

North American Securities Administrators Association (NASAA), "Broker-Dealer Fee Survey," Working Paper, 2014

Opiela, Nancy, "Are Compliance Issues Changing the Nature of the Financial Planning Business?" Journal of Financial Planning, Vol. 18, No. 4, 2005, pp. 36-45.

-------, "The Future of Fees," Journal of Financial Planning, Vol. 19, No. 8, 2006, pp. 24-31.

Ortman, John, "Fee Disclosure's Silver Lining; As Retirement Plan Advisers Implement Their Fee Disclosure Plans, Many Are Finding That Opportunity Is Knocking Loudly," Employee Benefit Advisor, 2011, pp. 20-20.

Oxford Economic Research Associates (OXERA), "An Assessment of Soft Commission Arrangements and Bundled Brokerage Services in the UK," April 2003. As of May 30, 2012:

http://www.fsa.gov.uk/pubs/cp/cp176_oxera_assessment.pdf

Palaveev, Philip, "Be Careful What You Wish for", Financial Planning, Vol. 38, No. 6, June 1, 2008, pp. 78-81.

Palmiter, Alan R., and Ahmet E. Taha, "Mutual Fund Investors: Sharp Enough?" Journal of Financial Transformation, 2008, pp. 113-121. As of May 20, 2012: www.canadianfundwatch.com/files/sharp-enough.pdf

Paterson, Jeffrey S., and Adrian Valencia. "The Effects of Recurring and Nonrecurring Tax, AuditRelated, and Other Nonaudit Services on Auditor Independence." Contemporary Accounting Research, Vol. 28, No. 5, 2011, pp. 1510-1536.

PLANSPONSOR, 2010 DC Survey, 2010. As of October 30, 2011:

http://www.plansponsor.com/2010_DC_Survey.aspx

Popova, Vera, What Renders Financial Advisors Less Treacherous? Working paper, June 23, 2010.

Pressman, Aaron, and Amy Borrus, "Fee-Based Accounts: A Poor Fit for Investors?" 
BusinessWeek, No. 3932, 2005, pp. 78-79.

Quick, Reiner, Matthias Sattler, and Daniela Wiemann. "Agency conflicts and the demand for non-audit services." Managerial Auditing Journal, Vol. 28, No. 4, 2013, pp. 323-344.

Rennekamp, Kristina. "Processing fluency and investors' reactions to disclosure readability." Journal of Accounting Research, Vol. 50, No. 5, 2012, pp. 1319-1354.

Revell, Janice, "Are Your Savings Safe? The Seamy Side of Pension Funds," Fortune, Vol. 146, No. 3, 2002, pp. 105-106.

Robinson, John H., "Who's the Fairest of Them All? A Comparative Analysis of Financial Advisor Compensation Models," Journal of Financial Planning, Vol. 20, No. 5, 2007, pp. 56-65.

Ryan, Paul, and Richard J. Taffler, "Do Brokerage Houses Add Value? The Market Impact of UK Sell-Side Analyst Recommendation Changes," British Accounting Review, Vol. 38, No. 4, 2006, pp. 371-386.

Sah, Sunita, and George Loewenstein. "More Affected= More Neglected Amplification of Bias in Advice to the Unidentified and Many." Social Psychological and Personality Science, Vol. 3, No. 3, 2012, pp. 365-372.

"Second thoughts on second opinions: Conflicted advisors exaggerate more when they know they will be second-guessed." Duke University Working paper, 2011.

"Nothing to Declare: Mandatory and Voluntary Disclosure Leads Advisors to Avoid Conflicts of Interest" Psychological Science Vol. 25, No. 2, pp. 575-584.

Sah, Sunita, George Loewenstein, and Daylian M. Cain. "The burden of disclosure: increased compliance with distrusted advice." Journal of personality and social psychology, Vol. 104, No. 2, 2013, pp. 289-304.

Sah, Sunita, Don A. Moore, and Robert J. MacCoun. "Cheap talk and credibility: The consequences of confidence and accuracy on advisor credibility and persuasiveness." Organizational Behavior and Human Decision Processes, Vol. 121, No. 2, 2013, pp. 246255.

Schwartz, Janet A., Francesca Gino, and Dan Ariely, "Experts Know Best, But for Whom? Understanding Conflicts of Interest in the Marketplace," Society for Judgment and Decision Making 32nd Annual Conference, 2011.

Schwartz, Janet, Mary Frances Luce, and Dan Ariely. "Are Consumers Too Trusting? The Effects of Relationships with Expert Advisers." Journal of Marketing Research, Vol. 48, 2011, pp. S163-S174.

Schwartz, Janet A., Mary Frances Luce, and Dan Ariely, "Do Relationships Affect Advice-taking?" Society for Judgment and Decision Making 32nd Annual Conference, Seattle, Wash., 2011.

SEC, Protecting Senior Investors: Report of Examinations of Securities Firms Providing 'Free Lunch' Sales Seminars, Office of Compliance Inspections and Examinations, September 2007. As of May 30, 2012: http://www.sec.gov/spotlight/seniors/freelunchreport.pdf

Sette, Enrico. "Competition and optimistic advice of financial analysts: Evidence from IPOs." Journal of Financial Intermediation, Vol. 20, No. 3, 2011, pp. 441-457.

Siggelkow, Nikolaj, Expense Shifting: an empirical study of agency costs in the mutual fund industry, Center for Financial Institutions, Working Paper No. 99-09, January 1999.

Spindler, James C., “Communication by Other Means," Regulation, Vol. 28, No. 2, 2005, pp. 48- 
53.

---------, "Conflict or Credibility: Research Analyst Conflicts of Interest and the Market for Underwriting Business," Journal of Legal Studies, Vol. 35, No. 2, 2006, 303-325.

Stoughton, Neal M., "Moral Hazard and the Portfolio Management Problem," Journal of Finance, Vol. 48, No. 5, 1993, pp. 2009-2028.

Stoughton, Neal M., Youchang Wu, Josef Zechner, "Intermediated Investment Management," Journal of Finance, Vol. 66, No. 3, 2011, pp. 947-980.

The ESOP Association, ESOP Statistics, undated. As of May 30, 2012: http://www.esopassociation.org/media/media_statistics.asp

Tkac, Paula A., "Mutual Funds: Temporary Problem or Permanent Morass?" Federal Reserve Bank of Atlanta Economic Review, Vol. 89, No. 4, 2004, pp. 1-21.

Transamerica Center for Retirement Studies, "The New Retirement: Working," 12th Annual Transamerica Retirement Survey, May 2011. As of May 30, 2012: http://www.transamericacenter.org/resources/TCRS12thAnnual\%20WorkerNewRetire mentFINAL05162011.pdf

United States General Accounting Office (GAO), 401(k) Plans: Improved Regulation Could Better Protect Participants from Conflicts of Interest, GAO-11-119, January 2011. As of May 30, 2012:

http://www.gao.gov/assets/320/315363.pdf

, Defined Benefit Pensions: Conflicts of Interest Involving High Risk or Terminated Plans

Pose Enforcement Challenges, GAO-07-703, June 2007. As of May 30, 2012:

http://www.gao.gov/new.items/d07703.pdf

-, Investment Banks: The Role of Firms and Their Analysts with Enron and Global Crossing, GAO-03-511, March 2003a. As of May 30, 2012:

http://www.gao.gov/new.items/d03511.pdf

-, Mutual Funds: Information on Trends in Fees and Their Related Disclosure, GAO-03-

551T, March 12, 2003b. As of May 30, 2012:

http://www.gao.gov/assets/90/81943.pdf

---------, Mutual Funds: SEC Should Modify Proposed Regulations to Address Some Pension Plan Concerns, GAO-04-799, July 2004a, p. 1. As of May 30, 2012:

http://www.gao.gov/assets/250/243339.pdf

---------, Mutual Funds: Additional Disclosures Could Increase Transparency of Fees and Other Practices, GAO-04-317T, January 2004b. As of May 30, 2012:

http://www.gao.gov/assets/120/110547.pdf

---------, Mutual Funds: Assessment of Regulatory Reforms to Improve the Management and Sale of Mutual Funds, GAO-04-533, March 10, 2004c. As of May 30, 2012:

http://www.gao.gov/assets/120/110666.pdf

---------, Mutual Funds: Additional Disclosures Could Increase Transparency of Fees and Other Practices: GAO-03-909T, June 18, 2003c. As of May 30, 2012:

http://www.gao.gov/assets/120/110547.pdf

---------, Mutual Fund Fees: Additional Disclosure Could Encourage Price Competition:

GAO/GGD-00-126, June 5, 2000. As of May 30, 2012:

http://www.gao.gov/assets/160/156959.pdf

Von Gaudecker, Hans-Martin, "How Does Household Portfolio Diversification Vary with 
Financial Sophistication and Advice?" MEA Discussion Paper No. 238-11, March 22, 2011.

Wang, Hefei, "Reputation Acquisition of Underwriter Analysts - Theory and Evidence," Journal of Applied Economics, Vol. 12, No. 2, 2009, pp. 331-363.

Weinberg, Neil, “A Bribe by Any Other Name," Forbes, Vol. 173, No. 8, April 19, 2004, pp. 54-56. Westphal, James D., and Michael B. Clement, "Sociopolitical Dynamics in Relations Between Top Managers and Security Analysts: Favor Rendering, Reciprocity, and Analyst Stock Recommendations," Academy of Management Journal, Vol. 51, No. 5, 2008, pp. 873897.

Willis, Richard H., "Mutual Fund Manager Forecasting Behavior," Journal of Accounting Research, Vol. 39, No. 3, December 2001, pp. 707-725.

Womack, Kent L. “Do Brokerage Analysts' Recommendations Have Investment Value?" Journal of Finance, Vol. 51, No. 1, 1996, pp. 137-167.

Yaniv, Ilan, "Receiving Other People's Advice: Influence and Benefit," Organizational Behavior \& Human Decision Processes, Vol. 93, No. 1, 2004, pp. 1-13.

Zhao, Xinge, The Role of Brokers and Financial Advisors Behind Investments into Load Funds, China Europe International Business School working paper, December 2005. As of May 30, 2012:

http://www.ceibs.edu/knowledge/papers/images/20060317/2845.pdf 


\section{Appendix 1: Review Methodology}

The initial review was conducted between 10/10/11 and 11/29/11, and then updated in September, 2013, and again in August 2014. The process consisted of: an initial identification of literature; several stages of evaluation to determine relevance; an initial synthesis of the relevant articles; a review of the first draft and solicitation of comments from experts at RAND, DOL and the academic community; an updated synthesis in light of comments received and additional literature identified.

The initial identification of literature was conducted via three methods: a systematic bibliographic database search of published articles and reports [see Appendix 2 for databases and systematic search strategy]; mining bibliographies from select papers; and a purposive search of working papers. The literature in our search included academic peer-reviewed journal articles, academic working papers, government reports, and trade journal and news articles.

After the initial identification of papers, the titles and abstracts were scanned for topic relevance by a team of 7 researchers: clearly irrelevant articles were discarded. A second round of evaluation was conducted on each category using full-text articles: any articles determined to be irrelevant in full-text were discarded; key points from the remaining articles were summarized. Bibliographies from highly relevant papers were mined for additional papers, and the IDEAS-REPEC database was searched by hand for additional working papers of interest; these papers were summarized in the same manner as the systematic search papers. The first draft was synthesized based on the article key-point summaries, with particularly important papers examined in more detail.

The first draft was reviewed by DOL and concurrently submitted to additional experts at RAND and in the wider academic community. Helpful comments on the substance of the review were received, along with suggestions for additional literature germane to the review topic. The final draft incorporates many insights based on this feedback, and additional sources were cited in the final draft. 
Appendix 2: Systematic Search Strategy

RAND Librarians conducted three searches. Each search used the same databases: Business Source Premier; EconLit; Index to Legal Periodicals; LexisNexis Industry News Publications; Web of Science

The initial search was restricted to publication dates between January $1^{\text {st }}, 1995$ and October $10^{\text {th }}, 2011$ The first follow-up search was restricted to publication dates between January $1^{\text {st }}, 2011$ and September $15^{\text {th }}, 2013$; each search examined the subject, title and abstract of the article for appearance of a combination of keyword terms, as described below:

Search 1

\begin{tabular}{|c|c|c|c|}
\hline Any one of... & AND Any one of... & $\begin{array}{l}\text { AND Any one } \\
\text { of... }\end{array}$ & $\begin{array}{l}\text { AND Any one } \\
\text { of... }\end{array}$ \\
\hline $\begin{array}{l}\text { conflict of interest } \\
\text { conflicts of interest } \\
\text { conflict of interests } \\
\text { conflicted } \\
\text { biased } \\
\text { principal-agent } \\
\text { principal agent } \\
\text { moral hazard } \\
\text { information asymmetry } \\
\text { disclosure } \\
\text { self-dealing } \\
\text { prohibited transaction } \\
\text { kickback } \\
\text { commission } \\
\text { malpractice } \\
\text { incentives } \\
\text { Conflict of incentives } \\
\text { Different incentives } \\
\text { affiliations }\end{array}$ & $\begin{array}{l}\text { Investor } \\
\text { investors } \\
\text { investments } \\
\text { investment } \\
\text { finance } \\
\text { financial } \\
\text { mutual funds } \\
401 \mathrm{k} \\
401(\mathrm{k}) \\
\text { IRA } \\
\text { Roth } \\
\text { Retirement savings plans } \\
\text { Defined-contribution plans } \\
\text { Defined contribution plans } \\
\text { Pension plans } \\
\text { Retirement savings } \\
\text { account } \\
\text { Retirement plans } \\
\text { Retirement planning } \\
\text { Retirement accounts }\end{array}$ & $\begin{array}{l}\text { advice } \\
\text { advisor } \\
\text { adviser } \\
\text { broker } \\
\text { dealer } \\
\text { audit } \\
\text { audits } \\
\text { education } \\
\text { recommendation }\end{array}$ & $\begin{array}{l}\text { cost } \\
\text { benefit } \\
\text { value } \\
\text { evaluation } \\
\text { evaluating } \\
\text { impact } \\
\text { estimate } \\
\text { effect } \\
\text { size } \\
\text { magnitude } \\
\text { price } \\
\text { fee } \\
\text { performance } \\
\text { outcomes }\end{array}$ \\
\hline
\end{tabular}

Search 2

\begin{tabular}{|l|l|l|}
\hline Any one of... & AND Any one of... & $\begin{array}{l}\text { AND Any one } \\
\text { of... }\end{array}$ \\
\hline $\begin{array}{l}\text { conflict of interest } \\
\text { conflicts of interest } \\
\text { conflict of interests } \\
\text { conflicted }\end{array}$ & - ESOP & - Employee Stock \\
$\begin{array}{l}\text { biased } \\
\text { principal-agent } \\
\text { principal agent } \\
\text { moral hazard } \\
\text { information asymmetry }\end{array}$ & - Employee stock options & valuation \\
fair market \\
value \\
market value \\
market price \\
fairness \\
opinions \\
audit
\end{tabular}




\begin{tabular}{|l|l|l|}
\hline disclosure & & audits \\
self-dealing & appraiser \\
prohibited transaction & & \\
kickback & & \\
commission & & \\
malpractice & \\
Conflicting incentives & & \\
Conflict of incentives & & \\
Different incentives & & \\
affiliations & \\
\hline
\end{tabular}

Search 3

\begin{tabular}{|c|c|c|}
\hline Any one of... & AND Any one of... & $\begin{array}{l}\text { AND Any one } \\
\text { of... }\end{array}$ \\
\hline $\begin{array}{l}\text { conflict of interest } \\
\text { conflicts of interest } \\
\text { conflict of interests } \\
\text { conflicted } \\
\text { biased } \\
\text { principal-agent } \\
\text { principal agent } \\
\text { moral hazard } \\
\text { information asymmetry } \\
\text { disclosure } \\
\text { self-dealing } \\
\text { prohibited transaction } \\
\text { kickback } \\
\text { commission } \\
\text { malpractice } \\
\text { Conflicting incentives } \\
\text { Conflict of incentives } \\
\text { Different incentives } \\
\text { affiliations }\end{array}$ & $\begin{array}{l}\text { Retirement platform } \\
\text { Retirement platforms } \\
\text { Retirement plan service } \\
\text { Retirement plan services }\end{array}$ & $\begin{array}{l}\text { advice } \\
\text { advisor } \\
\text { adviser } \\
\text { broker } \\
\text { dealer } \\
\text { audit } \\
\text { audits } \\
\text { provider } \\
\text { providers }\end{array}$ \\
\hline
\end{tabular}

The second follow-up search was restricted to publication dates between January 1, 2013 and July 15, 2014 and was more narrow in scope.

Search 1

\begin{tabular}{|l|l|l|l|}
\hline Any one of... & AND Any one of... & $\begin{array}{l}\text { AND Any one } \\
\text { of... }\end{array}$ & AND Any one of... \\
\hline $\begin{array}{l}\text { conflict of interest } \\
\text { conflicts of interest } \\
\text { conflict of interests }\end{array}$ & $\begin{array}{l}\text { investor } \\
\text { investors } \\
\text { investments }\end{array}$ & $\begin{array}{l}\text { advice } \\
\text { advisor } \\
\text { adviser }\end{array}$ & $\begin{array}{l}\text { cost } \\
\text { benefit } \\
\text { value }\end{array}$ \\
\hline
\end{tabular}




\begin{tabular}{|l|l|l|l|}
\hline conflicted & investment & broker & evaluation \\
biased & finance & evaluating \\
principal-agent & financial & education & impact \\
principal agent & mutual funds & recommendation & estimate \\
moral hazard & $401 \mathrm{k}$ & & effect \\
information asymmetry & $401(\mathrm{k})$ & & size \\
disclosure & IRA & & magnitude \\
self-dealing & Roth & & price \\
prohibited transaction & Retirement savings plans & & fee \\
kickback & Defined-contribution plans & & performance \\
commission & Defined contribution plans & & outcomes \\
malpractice & Pension plans & \\
incentives & Retirement savings account & & \\
Conflict of incentives & Retirement plans & & \\
Different incentives & Retirement planning & & \\
affiliations & Retirement accounts & & \\
\hline
\end{tabular}

Search 2

\begin{tabular}{|l|l|l|}
\hline Any one of... & AND & AND Any one of... \\
\hline conflict of interest conflicts & Retirement & advice \\
of interest conflict of & & advisor \\
interests & & adviser \\
conflicted & & broker \\
biased & & audit \\
principal-agent & audits \\
principal agent & provider \\
moral hazard & providers \\
information asymmetry & & \\
disclosure & \\
self-dealing & \\
prohibited transaction & & \\
kickback & \\
commission & & \\
malpractice & \\
Conflicting incentives & & \\
Conflict of incentives & & \\
Different incentives & & \\
\hline
\end{tabular}

